\title{
Aoristo)))))
}

International Journal of Phenomenology, Hermeneutics and Metaphysics

\section{No entremeio de abismos: entre pensamento e fé}

\author{
In-between chasms: between thought and faith
}

\author{
Prof. Dr. Marcos Aurélio Fernandes \\ Departamento de Filosofía da Universidade de Brasilia - UNB'
}

\section{RESUMO}

Este artigo procura pensar a filosofia, seu abismo e sua pobreza de espírito, por um lado, e a fé, seu abismo e sua pobreza de espírito, por outro lado. Pensa a ambos à luz da liberdade da verdade do Ser. Pensa o pensar e o crer como modalidades diversas de experiências transcendentais, ontológicas. Em cada uma dessas modalidades está em jogo o relacionamento com o nada. Procura seguir o sentido do fenômeno da fé primordial em sua vigência ontológica, vendo-o se desdobrando na fé abraâmica em geral e, em especial, na fé cristã. Na fé de Jesus Cristo vigente em São Francisco e sua existência vislumbra o mistério da "Senhora Pobreza". Este foi o tesouro do coração de frei Hermógenes Harada, pensador fenomenológo e frade franciscano, a quem, aqui, prestamos homenagem.

\section{PALAVRAS-CHAVE}

Abismo; Filosofia; Fé; Verdade do ser; Nada; Pobreza

\section{ABSTRACT}

This article seeks to think about philosophy, its abyss, and its poverty of spirit, on the one hand, and faith, its abyss, and its poverty of spirit, on the other. It meditates on both in the light of the freedom of the truth of Being. It tries to think the meaning of thinking and believing as different modalities of transcendental, ontological experiences. In each of these modalities the relationship with nothingness is at work. It tries to follow the sense of the phenomenon of the primordial faith in its ontological vigor, seeing it unfold in the Abrahamic faith in general and, especially, in the Christian faith. In the faith of Jesus Christ at work in St. Francis and his existence seeks to glimpse the mystery of "Lady Poverty". This was the treasure of the heart of Hermogenes Harada, a phenomenologist and Franciscan friar, to whom here we pay homage.

\footnotetext{
${ }^{1}$ E-mail: $\underline{\text { maffernandes69@gmail.com. Orcid: https://orcid.org/0000-0001-8928-1723 }}$
}

\author{
Marcos Aurélio Fernandes \\ Toledo, v. 4, n*1 (2021) p. 217-249
}




\section{Aoristo)))))}

International Journal of Phenomenology, Hermeneutics and Metaphysics

\section{KEYWORDS}

Abyss; Philosophy; Faith; Truth of being; Nothing; Poverty

\section{INTRODUÇÃO}

Em "De estudo, anotações obsoletas", o frei Hermógenes Harada sonda as pressuposições de uma "ratio studiorum" franciscana. (HARADA, 2009) Esta investigação na direção dos fundamentos dos estudos assumidos segundo a forma de vida dos Irmãos Menores, leva-o a tentar pensar o essencial do estudo, do trabalho acadêmico, da formação intelectual, assim como de três níveis de ciências: as ciências positivas, a filosofia e a teologia. A filosofia é o exercício da questão do sentido do ser. A teologia, por sua vez, é uma ressonância, um desdobramento e uma articulação em termos de ciência (mathesis universalis) e de sapiência (saber enquanto sabor) da existência na afeição obediente da fé. Numa interpretação sui generis da essência da teologia a partir da palavra-guia "fides quaerens intellectum", Harada evoca e tematiza o relacionamento entre a afeição obediente da fé e a busca questionadora do intelecto como abismo invocando abismo.

Harada esteve entre nós como pensador. Como pensador, ele viveu no entremeio entre estes dois abismos: o da questão do ser, que perfaz a busca do intelecto, do pensamento enquanto filosofia e o da afeição obediente da fé, que origina uma ciência peculiar e uma sapiência toda própria, chamada teologia. Nesse entremeio, ele, por assim dizer, escutou a mútua invocação dos abismos. Insistindo neste entremeio, sempre de novo, foi-lhe sendo dado o "pouco saber" e a "muita jovialidade", que se oferecem aos mortais como os melhores dons. Nosso propósito, aqui, é aprofundar esta colocação desse japonês, que migrou ao Brasil e que viveu em vários continentes (Ásia, América, Europa, África) e que, pela sua busca intelectual na experiência do pensar filosófico e, ao mesmo tempo, pelo vigor e ternura de sua mística e franciscana fé, deixou que a finitude de sua existência florescesse como obra perfeita da liberdade.

\section{A FILOSOFIA: SEU ABISMO E SUA POBREZA DE ESPÍRITO}

O que há com a filosofia? O estudo da filosofia é muito peculiar. Para salvaguardar esta peculiaridade, é preciso, sempre de novo, recordar que a filosofia pertence àquelas coisas inúteis, que, nessa mesma inutilidade, isto é, na impossibilidade de serem reduzidas a instrumento para o que quer que seja, se afirmam na sua nobreza e importância. Duas estórias do sábio chinês Chuang-Tzu nos falam da importância do não-útil. Evoquemos, aqui, estas duas estórias, que, na verdade, são dois diálogos entre Hui Tzu e Chuang Tzu.

Hui Tzu disse a Chuang: Tenho uma grande árvore, que se chama "malcheirosa". Seu tronco tão torto é tão cheio de nós que ninguém pode dele tirar uma só tábua. Os galhos são tão retorcidos que você 


\title{
Aoristo)))))
}

\section{International Journal of Phenomenology, Hermeneutics and Metaphysics}

não consegue cortá-los de modo a que sejam úteis. Lá está ela à beira da estrada. Carpinteiro nenhum a olhará. Eis o seu ensinamento grande e inútil.

Respondeu-lhe Chuang Tzu: Já viu o gato do mato agachado, espreitando a sua presa -, pula assim e assim, para cima e para baixo, e por fim cai na armadilha. Mas o iaque, já viu? Poderoso qual trovão mantém-se com a sua força. Grande? Claro que sim, mas não sabe pegar ratos! Assim, a sua árvore inútil. Inútil? Plante-a então no terreno baldio sozinha e caminhe a esmo, em torno dela, descanse à sua sombra; nenhum machado ou decreto proclamará o seu fim. Ninguém jamais a abaterá. Inútil? Que me importa?. (MERTON, 2002, p. 61-62)

A grande e inútil árvore de Hui Tzu é importante, diz Chuang-Tzu. Sua importância não vem de uma utilidade imediata e determinada. Sua importância consiste no que ela é e como ela é, na nobreza e grandeza de seu ser mesmo. Mas esta importância se abre quando o homem deixa de caminhar pelos caminhos já abertos e batidos do que é instrumental, do que é meio para um fim, do que tem um "para quê". O horizonte de sua importância se abre e deixa aparecer seu sentido, quando o homem se relaciona com ela para além ou para aquém do inter-esse da produção, da sobrevivência, do mérito, do ganho, do lucro. Não se abre nem mesmo se ainda a consideramos como "objeto" de fruição, no horizonte do "agradável", no interesse do prazer e do lazer e do descanso. A sua importância é tal que a faz estar aquém ou além desses horizontes de sentido e resistir e persistir de modo a se poder dizer: "ninguém jamais a abaterá". Nem por decreto. Não se proclama o seu fim com o mando do poder ou com o poder do mando, da dominação.

Análoga à árvore grande e inútil de Hui Tzu é a filosofia. "Inútil? Que me importa?". Entenderíamos mal esta pergunta como se fosse uma reação defensiva, sentida e ressentida, em face ao utilitarismo crasso ou ao pragmatismo tosco de nosso tempo. Essa reação ainda seria negativa: negação da negação. A quem nega a filosofia em seu valor, em sua importância, em sua "utilidade", se responderia com uma negação da negação, afirmando sua importância em si mesma. O que Chuang Tzu talvez nos induza a ver está em outra dimensão, em outro interesse, em outra perspectiva de sentido. Trata-se de um horizonte não negativo. Não negativo significa: nem negação, nem negação da negação. A grande e inútil e malcheirosa árvore de Hui Tzu - e assim seria a filosofia - é algo assim como a "rosa sem por quê" de Ângelus Silesius, que, em seu "Peregrino Querúbico", livro I, n. 289, canta:

A rosa é sem por quê

Floresce por florescer

Não olha p'ra seu buquê

Nem pergunta se alguém a vê.

(SILESIUS, 1989, p. 156)

\author{
Marcos Aurélio Fernandes \\ Toledo, v. 4, n*1 (2021) p. 217-249
}




\section{Aoristo)))))}

International Journal of Phenomenology, Hermeneutics and Metaphysics

Talvez a pergunta que soa como uma exclamação: "Inútil? Que me importa?" esteja apenas tomando distância de ação e reação, para, na não-ação, que é a ação perfeita, pois consuma a relação de ser com o ser daquilo que está em questão, deixa ser a importância da árvore em seu auto-esquecimento mesmo. A árvore não se sabe como importante. Não olha para si mesma. Não pergunta se alguém a vê. Apenas está ali. Cresce por crescer. Verdece por verdecer. Floresce por florescer. Do seu jeito... Assim, toda retorcida, vil, como as nossas árvores do cerrado. O sentido da árvore se abre para aquele que é capaz de ver a dimensão da gratuidade, do sem por quê. É a dimensão de fundo de tudo aquilo que há... de tudo que está sendo... de tudo o que cresce e concresce por si mesmo e de tudo o que surge por meio do trabalho, da produção humana, do empenho, do mérito humano. Esse fundo se retrai em si mesmo. Vige como abismo da gratuidade. Vige, sem por quê... Vige numa espécie de auto-esquecimento, de inocência... Vige como pura gênese, como fontal nascividade, como serena jovialidade e jovial serenidade. Ora, essa vigência nós chamamos de "mistério do ser".

O pensar é sempre o pensar do mistério do ser. É "do" em dois sentidos: tanto no sentido de que o pensar é chamado em causa por e provocado a pensar o mistério do ser - em outras palavras: o mistério de ser é o puro fenômeno, que constitui a tarefa, a coisa ela mesma do pensar; quanto no sentido de que o "mistério do ser", deixa-ser o pensar, tal qual clareira de sua auto-abertura e auto-irrupção, de sua auto-iluminação. E filosofia, filosofar, é aquele estudo, ou seja, aquele empenho de deixar o pensar se consumar na sua pertença e correspondência ao "mistério do ser", e ao chamado, ao apelo, de sua Linguagem, de seu "lógos". Todo o saber filosófico consiste só em proteger e resguardar no pensar a verdade (revelação) do mistério do ser. Todo o conhecimento filosófico é só co-nascer com o vigor desse pensar do mistério do ser. "Só" - quer dizer: esse pouco é tudo. Quer dizer também: esse pouco é pouco em "quantidade", mas é muito, superabundante, superfluente, em sua potencialidade. É como a "semente de mostarda" da parábola evangélica (Mt 13, 3132): pouco saber, que traz muita jovialidade consigo. Pode, com efeito, fazer muito conosco. De fato, se não podemos fazer nada com a filosofia - eis a sua inutilidade ela, no entanto, pode fazer muito conosco, isto é, pode fazer conosco aquilo que nos é mais necessário, em sua essencialidade - eis a sua importância. A segunda estória é a seguinte.

Hui-tzu disse a Chuang-tzu: "Você fala do não necessário". Chuangtzu falou: "primeiramente carece de alguém reconhecer o não necessário, antes de poder falar com ele do necessário. A terra é larga e grande, e, no entanto, o homem carece, para ficar de pé, só aquela porção de lugar necessária para que ele pise. Caso, porém, imediatamente, ao lado dos pés, surgisse uma fenda que afundasse até o subterrâneo, o lugar sobre o qual ele está ainda lhe seria útil para algo?" Hui-tzu falou: "não lhe seria mais útil para nada". Falou, então,

No entremeio de abismos: entre pensamento e fé 


\title{
Aoristo)))))
}

\section{International Journal of Phenomenology, Hermeneutics and Metaphysics}

Chuang-tzu: "daí resulta com clareza a necessidade do não necessário. (apud HEIDEGGER, 1995, p. 239; Cf. MERTON, 2002, p. 225-226)

Chamamos de pobreza de espírito a receptividade para a riqueza essencial do não necessário, isto é, do desútil. Chuang Tzu é um pensador da pobreza de espírito, isto é, pensa desde ela, nela, em favor dela. Hui Tzu é de opinião que o não imediatamente necessário, o desútil, é sem importância. Chuang Tzu, no entanto, mostra que o não imediatamente necessário, o "inútil" ou desútil, a amplidão do ser, é imprescindível mesmo para que o necessário, isto é, o útil, seja o que ele é, ou seja, algo que serve para outro algo. Chuang Tzu, o pensador chinês, poderia dizer com Hölderlin, o poeta da poesia: “Tudo se concentra para nós no espiritual, nós nos tornamos pobres, para nos tornarmos ricos". (apud HEIDEGGER, 2013, p. 871) Mas, o que é o espiritual? "Aquilo em que tudo se recolhe e a partir de que tudo o que veio a ser e virá a ser acontece a modo de evento, é 'o espiritual'”. (HEIDEGGER, 2013, p. 872) O espiritual é o lógos do ser, isto é, o lampejo de seu sentido - é o evento, isto é, a originária auto aparição do mistério do ser, que vige em tudo o que se vem a ser e acontece. O espiritual é determinado pelo espírito. Há, para nós, a concentração no espiritual, quando o espírito nos advém e sobrevém, e, assim, nos assalta, e nos toca, isto é, se torna o nosso interesse.

Da experiência do espírito, marcada por tal pobreza, isto é, por tal concentração no espiritual, é que surgiram, nos primórdios da história dos povos do oriente e do ocidente, há cerca de dois milênios e meio, as figuras do sábio (na Índia e na China), do profeta (no crescente fértil, mas sobretudo em Israel) e do pensador (na Grécia). (Cf. ROMBACH, 1977, p. 23-31)

O profeta experimentou o espírito como sopro e fogo sagrado, que sobre ele dispunha, e que o enviava a anunciar uma mensagem, contra a alienação de seu mundo, em favor do vigor divino que salva, provocando rupturas e revoluções na história.

O sábio experimentou o espírito não sobre si, mas em si. Esteve à disposição do espírito na busca da iluminação do olho da contemplação. Não o êxtase e o movimento de irrupção, mas o retorno para a interioridade, a imersão e o repouso, caracterizavam o espiritual nele. Não o anúncio de uma mensagem salvadora, mas a meditação, isto é, a vigência do nada da consciência na consciência, o diálogo que, em perguntas e respostas, apenas acena para o inefável, o recolhimento no luminoso silêncio.

O pensador experimenta o espírito como transcendência do relacionamento com o mistério de ser no exercício do pensar. Nesta transcendência, o ente (o "real") é ultrapassado, no relacionamento com o ser (a "realidade"), que, como diferença ontológica, nada é de ente. É o evento de gênese, a originária auto aparição da realidade, em que se recolhe e se expande toda a realização do real. É esta transcendência que possibilita ao homem ser um si-mesmo e erguer-se a si mesmo desde si mesmo, na dinâmica da criatividade, que traz em si "o fogo de Prometeu".

\author{
Marcos Aurélio Fernandes \\ Toledo, v. 4, n'1 (2021) p. 217 249
}




\section{Aoristo)))))}

International Journal of Phenomenology, Hermeneutics and Metaphysics

Trata-se de uma experiência de finitude. Finitude humana diz tanto imanência ôntica - precisar do comércio com o ente para ser o que é - quanto transcendência ontológica - precisar da liberdade da abertura e do lume da verdade do ser para ser o que é. No tocante à perspectiva ontológica, a finitude da experiência humana consiste em o homem precisar do ser (da sua abertura, da sua dimensão livre e leve) para ser o que ele é, em ter que se tornar desperto sempre de novo e de maneira nova para a sua simplicidade e riqueza, para sua unicidade e abissalidade. (cf. HEIDEGGER, 2001, p. 201; 1978, p. 198; 2010, p. 84) Finitude e transcendência, portanto, não se opõem e não se excluem. Pelo contrário. O homem é finito na medida em que é transcendente. Por seu turno, finitude e transcendência não excluem a autonomia. Pensar é experiência de finitude e transcendência, sendo experiência de autonomia, uma vez que, nesta experiência, o homem se autodetermina a si mesmo devindo o que ele é, medindo-se com o ente e com o ser.

As três figuras da experiência do espírito, foram primordiais para o princípio do viver dos povos, no oriente e no ocidente. Em virtude de tal primordialidade, elas não pertencem a um passado apenas pretérito, mas sim a um passado recolhido em sua vigência latente, que, sempre de novo, pode propiciar ao homem do presente, solicitado pelo porvir, novas possibilidades de ser homem humano.

Pois bem. A experiência da pobreza do espírito no pensar, na filosofia, é-lhe essencial. O espiritual não diz, aqui, o imaterial, o oposto à matéria. Enquanto meramente negativa, esta determinação do espiritual é insuficiente. Ela permanece dependente daquilo que ela nega. Mas, como alcançar uma concepção não negativa do espiritual? Há, na história do ocidente, um testemunho de tal concepção? Nos primórdios dessa história, o espírito chama-se pneu'ma (pneuma), e o espiritual é o pneumático. Pneu'ma (pneuma) diz sopro, hálito, ar, vento, respiração, vida. Espírito, na experiência pneumática, é "força atuante de iluminação e de sabedoria, em grego, sofiva (sophía)”. (HEIDEGGER, 2013, p. 874) Tal força é libertadora. Por isso, o espiritual, como pneumático, se experimenta como caminhada de libertação, desde a, na e para a abertura da verdade do ser. Caminhada, porém, é o fazer-se caminho do caminho no próprio caminhar, ou seja, é abrir-caminho. Nesta caminhada, não basta ao homem o fazer, o querer, o saber. É preciso que ele saiba o não saber, queira o não querer, deixe se fazer o não-fazer. É caminhada para a fonte e desde a fonte da vitalidade, do vigor da vida. A fonte da realidade, porém, se dá e acontece, deixando ser o manancial das realizações do real que dela irrompe, mas ela mesma, em si mesma, se oculta, se retrai. Pensar é seguir o retraimento na doação, entre querer e não querer, saber e não saber, fazer e não fazer. A fonte é "sem por quê" - gratuidade inesgotável. Pensar é tornar-se passagem para o jorrar dessa fonte. É, com outras palavras, ser todo ausculta do vigor do envio no abrir caminho da libertação. Pensar é ser-homem. E a essência do homem é deixar ser a passagem para a irrupção da realidade nas realizações do real. O caminho de todos os caminhos, o Tao, o Lógos da realidade, só vige doando-se e, ao mesmo tempo, retraindo-se, como o nada do mistério, nos envios das realizações do real. Desprendendo-se de todo o apego às realizações do real, de todo o próprio saber e não saber, querer e não querer, fazer e 


\title{
Aoristo)))))
}

International Journal of Phenomenology, Hermeneutics and Metaphysics

não fazer, ter e não ter, o homem se dispõe à cordialidade fontal da vida, com outras palavras, à jovialidade do mistério do ser. O espírito é o sopro da liberdade que tudo liberta e que salva, isto é, resguarda, protege, na sua essência, no seu vigor mais próprio. O espírito rege sem se impor, como suavidade da vida, como o recato do mistério, que se oculta, mas que, neste encobrimento, salva tudo o que vem à luz.

O espírito não é, aqui, portanto, substância, nem sujeito (figuras metafísicas do espírito). Desde a relação sujeito-objeto o homem não experimenta propriamente o espírito enquanto espírito. Permanece preso a seus projetos de tudo sujeitar a seu saber, querer, fazer, ter. A relação sujeito-objeto, na maior parte das vezes, é uma relação pautada pelo necessário, no sentido do útil. Os objetos são aquilo que nós sujeitamos em função de nossos projetos, são aquilo de que nós dispomos deste ou daquele modo, no interesse de nossos objetivos, de nossas metas, de nossos fins, a fim de satisfazer às penúrias que despertam em nós a necessidade (o domínio do útil e agradável, da sobrevivência e da comodidade). A pobreza do espírito é o elevar-se acima deste tipo de relacionamento com as coisas, com as pessoas, sim, com as nossas próprias vivências de querer e não querer, saber e não saber, fazer e não fazer, ter e não ter. É o tomar distância de tudo isso, para mais livremente se comprometer com tudo isso, desde a liberdade da revelação do ser. Pobreza de espírito é permanecer na elevação dessa relação de ser com o mistério de ser. É transcender o ente no relacionamento familiar, confiante, com o ser. A relação com o ser perfaz o homem. Mas, atenção: o ser não é nenhum ente (o real, o que está sendo), nem sequer é a entidade (a realização, a presença constante) do ente (do real); não é o modo de ser que perfaz o ente em seu caráter típico (essência, possibilidade) e nem o fato de o ente ser (existência, efetividade). $\mathrm{O}$ ser (a realidade em seu mistério) vige em tudo isso como fonte de tudo isso, como o evento da pura auto aparição da gênese, como medium silencioso que tudo media, que tudo permeia, que tudo transcende e que tudo circunda, como o elemento originário do pensar:

Aquilo que, de resto, se dá ao redor de nós, os contra-postos (= os objetos), nós chamamos também de o ente, que é. Mas este "é" no ente não é, ele mesmo, de novo, algo que está sendo, mas aquilo que, por primeira vez, deixa todo ente ser um sendo e que, por isso, cerca e envolve. Nós o chamamos de o Ser. A relação elevada, na qual o homem se finca, é a relação do Ser com o homem, de tal modo que o Ser mesmo é esta relação, que traciona para si a essência do homem enquanto aquela essência que está fincada nessa relação e, ficando firme dentro nela, a custodia e a habita. No aberto desta relação do Ser para com o homem experimentamos "o espírito" - que é o que rege a partir do Ser e, presumivelmente, em favor do Ser. (HEIDEGGER, 2013, p. 877)

A pobreza é o acontecer daquele evento, no qual aparece originariamente a concentração, o recolhimento na relação do Ser com nossa essência. Nesse evento, se

\author{
Marcos Aurélio Fernandes \\ Toledo, v. 4, nं1 (2021) p. 217-249
}




\section{Aoristo)))))}

International Journal of Phenomenology, Hermeneutics and Metaphysics

abre aquela esfera da revelação da realidade em gênese, cujo centro está em toda a parte, e cuja periferia está nenhures. A pobreza do espírito põe o homem nesse centro. Por isso, para ele tudo se concentra no espiritual, isto é, na liberdade da verdade do Ser. Ser pobre e ser rico, nesta dimensão de consideração, a do pensamento do Ser, não se define pela posse, pelo ter. Na dimensão do útil e da relação sujeito-objeto, ser pobre é um não ter, precisamente, um carecer do necessário (do imprescindível, do útil, do agradável, do cômodo). Ser rico é um não carecer do necessário. É um ter para além do necessário (ter o imprescindível e o supérfluo, o útil na sua versão "top", o agradável, o cômodo, em abundância). Mas, nesta dimensão de consideração do útil e da relação sujeito-objeto está em jogo uma pobreza e uma riqueza que não é a do Ser, central. Está em jogo uma pobreza e uma riqueza que é a do ter. Mas, quando se fala de pobreza de espírito visa-se a uma pobreza essencial, que é a pobreza na dimensão da relação Ser-homem. A essência da pobreza, que é a pobreza essencial, repousa, com efeito, em um Ser. Ser pobre de verdade, nesta dimensão originária, quer dizer: ser de tal modo que de nada se carece, a não ser do não-necessário (o desútil, o gratuito do Ser). É um não poder ser sem o não-necessário e a ele pertencer unicamente. $\mathrm{O}$ necessário é o que provém do aperto e advém através dele. $\mathrm{O}$ aperto oprime, constrange, constringe. O homem é, sempre de novo, pressionado a assegurar sua sobrevivência, a conservar-se em vida, satisfazendo suas precisões. É através do ter que ele providencia tal satisfação. Mas, não raro, ele é tido por este ter (e, do mesmo modo, pelo não-ter), perdendo a liberdade de ser, melhor, do Ser. Ele quer preencher o vazio de ser com a abundância do ter, com a demasia de posses. A ausência da pobreza de espírito leva, assim, a uma situação em que a ganância do lucro seja a regra a ditar todos os julgamentos e todos os comportamentos, aumentando a desigualdade econômico-social, isto é, a abundância excessiva de uns, a riqueza como excesso material, e a miséria extrema de outros, a pobreza como indigência material (o não ter o imprescindível). Neste mundo esquecido da pobreza de espírito, a do Ser, a satisfação, muitas vezes momentânea, das precisões, na forma do consumismo, é o que há de imperioso. A necessidade de sobrevivência, de segurança no e a partir do ter, de produzir e consumir, se torna exclusividade. Esquece-se, assim, o espírito: a liberdade

A liberdade é o vigor de ser do Livre. O livre, por sua vez, é o não danificado pelo uso e abuso, o não-útil. Livre é o que se contém, se detém, se abstém de apropriar para si, em favor de deixar-ser o outro no seu mais próprio. Nos relacionamentos do ter, só se pode dar o que se tem, o que se possui. Mas no relacionamento do Ser, dá-se o que não se tem, o que não se possui, dá-se ao outro o seu poder-ser outro. O Livre é algo como um nada criativo. No âmbito derivado das produções nada provém de nada. Mas no âmbito originário da criação, é do nada que tudo vem a ser. Trata-se de um vazio, de um sem forma, de que emergem as possibilidades de formação de tudo o que se perfaz na determinação de uma forma. A forma não é nenhuma coisa, é uma não coisa, um nada. Mas é justamente o seu nada que condiciona o vir a ser coisa da coisa. A forma libera à coisa o seu poder-ser coisa. É o que lemos no Tao Te King: 


\section{Aoristo)))))}

International Journal of Phenomenology, Hermeneutics and Metaphysics

Trinta raios estão sobre um cubo de roda,
No entanto, ali onde eles não estão
É que se encontra o sentido da roda.
A argila é amassada até virar cálice,
No entanto, ali onde o cálice não está
Está a utilidade do cálice.
Fixamos porta e janela na morada,
No entanto, ali onde não há nada
Está a essência da morada.
Vale, portanto:
Se apreendes alguma coisa em sua utilidade,
Apreenda então: o nada perfaz tudo.

(apud ROMBACH, 1988, p. 10)

Esse nada criativo pode ser chamado também de "caos". "Caos", aqui, não significa desordem. "Caos" significa, aqui, abertura da liberdade de Ser, que, de sua abissalidade, deixa irromper sempre novas possibilidades de realizações do real, criativamente, inesgotavelmente. Aquilo que é contido e protegido pelo Ser, na medida em que é, é abrigado na sua essência. Ser vige como acontecimento originário desse resguardar. O liberto é o que é deixado repousar em sua essência, o sereno, o jovial. $\mathrm{O}$ vigor da liberdade se dá como serenidade jovial e jovialidade serena. A liberdade é o que tem o poder de "dar uma volta" no necessário, de virá-lo, de contorná-lo. A liberdade é o que verte, converte, subverte a dinâmica do que aperta, oprime, constrange e constringe. Neste sentido, a liberdade, a da pobreza de Ser (do desprendimento), é o "único necessário", é a originária necessidade. Para o pobre no espírito, a possibilidade do ser-livre graças à liberdade da verdade do Ser, é a única necessidade. Não se trata, pois, da necessidade do necessário, do útil. Tratase, antes, da necessidade do não-necessário, do não-útil.

A pobreza de espírito do pensar é, pois, um não carecer de outra coisa do que da riqueza essencial, da riqueza do Ser. É a riqueza da fonte inesgotável da realidade em gênese, que já sempre, a priori, transborda todas as margens das realizações do real. É a riqueza do jorrar do mistério da gratuidade ou da gratuidade do mistério. Pobre é o que, no desprendimento, no abrir caminho para a liberdade se fazer, se expropria de tudo, para ser apropriado por essa riqueza fontal. Pobre é o que se afina com essa riqueza e se torna como ela é: livre-libertador, na serenidade jovial e na jovialidade serena. É o que re-duz todo ter e não ter, todo o fazer e não-fazer, todo o saber e não-saber, todo o querer e não-querer, à fonte do Ser. É aquele em que o esquecimento do espírito, isto é, da cordialidade da vida, da liberdade, está superado.

Heidegger, em 1959, quando celebrava setenta anos em sua cidade natal, Messkirch, acenava para o vínculo que vigora entre agradecer e pensar. Trata-se, 


\title{
Aoristo)))))
}

\section{International Journal of Phenomenology, Hermeneutics and Metaphysics}

melhor dizendo, de uma identidade. "Pois agradecer (danken) e pensar (denken) não são apenas a mesma palavra, são também a mesma coisa". (HEIDEGGER, 1977, p. 50) Agradecer é pensar, no sentido de recordar, de pensar em... a saber, na dádiva e sua doação. Não é, porém, remontar ao passado pretérito (das Vergangene). É remontar ao passado vigente, isto é, ao que vige latente na concentração de seu vigor (das Gewesene). A dádiva desse passado vigente não coincide apenas com o pensado e o dito de outrora, dos caminhos abertos pela tradição. Mas guarda em si, no nãopensado e no não-dito, outras possibilidades de ser, cujos caminhos ainda estão por se abrir. Estes caminhos, no entanto, só podem ser abertos na medida em que o homem se eleva na relação do Ser com ele mesmo. Na dádiva latente, esquecida, do Ser "ainda lhe estão (ao homem) reservadas e poupadas a plenitude e as profundezas do querer e poder". (HEIDEGGER, 1977, p. 50) Assim, o agradecer, como pensar, está disponível ao apelo do porvir. Sua memória, enquanto criativa, é uma memória do futuro. Heidegger, então, recorda uma sentença de Nietzsche, segundo a qual "o filósofo é uma planta rara". É um homem cuja originalidade do pensar consiste não no caráter de novidade, mas no caráter de originariedade. Ele diz:

\begin{abstract}
A originalidade do pensar não está em descobrir os chamados "novos" pensamentos. A originalidade própria do pensar está na força de se acolherem pensamentos já pensados, de se aturar o que se acolhe, e se desenvolver o que se atura no recôndito de sua intimidade. É então que os pensamentos alcançam por si mesmos o nível a que pertencem, o que chamo o "originário". É então que brota a paixão própria do pensamento, a paixão do "inútil". É então que cresce a compreensão, de que um pensamento só é verdadeiro pensamento, quando não necessitar ser útil sem nem precisar comparar-se com a utilidade. Só quando uma paixão assim tiver despertado, é que se poderá talvez conseguir por algum tempo ater-se ao caminho e vir a ser o que se chama de precursor. Refiro-me ao pre-cursor, não ao antecessor mas a quem antecipa na antecedência, sem que se note. (HEIDEGGER, 1977, p. 51)
\end{abstract}

O pobre é o que acolhe e recolhe a riqueza perdurante e duradoura do não necessário, no sentido do não útil. Ele percebe que nada é mais necessário do que o não útil. Inútil é o sentido das coisas. Com ele nada se pode fazer. Ele não serve para nada. Mas, sem ele, o próprio útil se defasa e se degenera. Filosofia é filosofar. E filosofar é gostar de investigar, de perseguir, de co-fazer, de seguir o sentido das coisas. É um deixar-se tracionar pelo relacionamento do Ser com o homem. Harada chamou isso de "medir-se com o ser.

A filosofia é o empenho de assumir explicitamente a transcendência da existência: o medir-se com o ser em sua verdade. Filosofia é, em sua forma e em seu conteúdo, simplesmente, questão do ser. E questão do ser é medir-se com o ser. Questão é o querer de uma busca radical. Nessa busca radical o homem se dispõe a querer o querer do seu querer e, por fim, a querer o não querer. É uma busca por e para ser. Essa busca conduz o homem para o centro da vida. Nesse centro, todas as 


\title{
Aoristo)))))
}

\section{International Journal of Phenomenology, Hermeneutics and Metaphysics}

perguntas fundamentais do homem se transformam numa única pergunta essencial: a pergunta do sentido do ser. "No centro, todo o nosso ser se transforma numa única pergunta. Todo o nosso ser é pergunta". O exercício da transcendência da existência na radicalidade do querer desta busca, da pergunta pelo sentido do ser, é a filosofia. É o medir-se com o ser, que Harada descreve assim:

Com outras palavras, a transcendência do querer é a busca do que foi e não foi, do que é e não é, do que será e não será, do que pode e não pode, por e para ser. É a responsabilidade de ser. Essa necessidade de aprofundar cada vez de novo, cada vez melhor e cada vez mais a busca do sentido do ser, radical e totalmente por e para ser, essa responsabilidade de ser é o que a formulação medir-se com quer dizer. Medir-se com o ser, a questão do ser, o querer enquanto o ser da existência, a responsabilidade de ser, a facticidade, a existencialidade, a existência, dizem o mesmo. E perfaz a existência do homem. Por isso não é o homem que se mede com o ser. Antes, é o medir-se com o ser que constitui o que é o homem e todas as suas possibilidades, o que ele é e não é. Isto significa que todo o ser do homem, em seus mínimos detalhes, em suas mínimas concreções, é a responsabilidade de ser. Não é ele a causa, o agente, o sujeito do ser. Nem o ser é a causa, o agente, o sujeito do homem. Não é o homem a medida do ser. Nem é o ser a medida do homem. Pois, nem o homem nem o ser são simplesmente de antemão. Homem, é, porém, na medida em que se mede com a responsabilidade de dever ser a busca e a acolhida do sentido do ser. E o sentido do ser se dá como o ser dos entes na sua totalidade, em se doando como penhor do empenho e como doação da busca e da acolhida. Podemos, pois, dizer que o homem é a abertura da decisão, através da qual se dá a determinação do sentido do ser dos entes na totalidade, inclusive do próprio homem. (HARADA, 1977, p. 39)

Na filosofia, isto é, no filosofar, o estar aberto para a abertura do Ser e a exposição a ele, se dá desde o despertar do questionamento explícito pelo sentido do Ser. É o despertar da filosofia. Desperto para o "círculo do desvelamento" (a verdade do Ser), o homem é instado a ser o seu cuidador, o seu guardador, o seu guardião, enfim, o seu pastor. Então, o ente no todo deixa de aparecer como factualidade opaca e surda, para aparecer como facticidade translúcida e ressonante. O ente, de objeto e ocorrência aí, se tornou o "sendo" do ser. Ele sofre uma transformação, que deixa aparecer o sentido do Ser. Este é algo assim como o tinir, o percutir e repercutir do Lógos. Nele aparece a vigência da verdade do ser.

De repente, a factualidade das coisas que são diante de mim, a factualidade da existência que sou eu mesmo, a factualidade de tudo quanto pode ser mas não é, de tudo quanto não é e não pode ser,

\author{
Marcos Aurélio Fernandes \\ Toledo, v. 4, n*1 (2021) p. 217-249
}




\section{Aoristo)))))}

International Journal of Phenomenology, Hermeneutics and Metaphysics

enfim, os entes na sua totalidade, inclusive a mim mesmo que penso e digo essa totalidade, se acham ali presentes numa presença que não é oposta à ausência, mas sim numa presença que é "algo" como um abrir-se, como um clarear-se do sentido do ser. Essa abertura, essa clareira se chama facticidade e perfaz propriamente o ser da existência. Enquanto ser da existência se chama também existencialidade. (HARADA, 1977, p. 38)

Filosofia não é doutrina. Filosofia é atividade, como dizia Wittgenstein. Melhor dizendo: filosofia é ação, isto é, consumação da referência, da relação, do Ser com o homem. Tudo que na filosofia aparece como doutrina e seus sucedâneos (sistemas, teorias, conhecimentos, informações; mundividências, convicções, ideologias), nas variantes de seus mil e mil "ismos", encobre a essência da filosofia. As "filosofias" precisam ser, sempre de novo, destruídas. Destruir quer dizer, porém: des-montar, para re-montar às fontes da experiência do pensar, ao seu movimento de busca, ao seu nascedouro, às suas intuições fundantes. Por isso, a formação filosófica não se mede pela quantidade de informações. Ela se mede pela qualidade e essencialidade da intelecção. A inteligência filosófica não é a do cálculo. É a da capacidade de perseguir e seguir o "sentido das coisas". Essa inteligência não é aquela que se opõe ao espírito no afã da mera sujeição do real na perspectiva, no enfoque, do útil (relação sujeito-objeto). É aquela que se identifica com o espírito, no cuidado, no "pastoreio", do sentido do Ser. Essa inteligência é, se nos é permitido dizer assim, "inter-legência", isto é, capacidade de entre-ler, de entre-colher, de re-colher o sentido em seu nascedouro, a cada vez, em cada passo do caminho de busca do pensar. É re-colher e resguardar a verdade do Ser (céu e terra, mortais e divinos). É suportar permanecer na tensão criativa da espera do inesperado. É algo como o estar sempre de novo desperto para uma "memória do futuro". É a constante abertura para a acolhida do "medium" silencioso do mistério de Ser, que, sempre o mesmo, mas nunca igual, permeia todas as possibilitações e realizações do que está sendo, do que vem a ser. É algo como uma acolhida, uma obediência, isto é, uma ausculta para o tinir e retinir do sentido do Ser. Afinação. Harmonia como o Lógos. A inteligência, assim, é espírito. O estudo, o trabalho intelectual do filósofo é, assim, espiritual. E é como guardião dessa inteligência que é espírito que ele presta o obséquio de ser "servidor da humanidade". Assim, ensinar filosofia nada tem a ver com doutrinação. É, antes, deixar aprender o aprender a pensar - especialmente através do co-pensar com aqueles que são ditos "os pensadores", suportando sondar no seu pensado e dito o não pensado e não dito, no caminho para a dimensão da originariedade.

Filosofia é medir-se com o Ser. É filosofar, ou seja, é deixar-ser "a presença e plenitude da totalidade dinâmica da possibilidade da vida, no nosso viver, em sendo, na pregnância da evidência imediata da coisa ela mesma", deixando aparecer, assim, a cada passo da busca, sempre de novo, o que Husserl chamou de "mundo da vida", ou melhor, o que Heidegger chamou de "Da-sein”, "o espaço aberto da plenitude da possibilidade, que poderíamos chamar de insondável abismo desvelante das possibilidades do ser". (HARADA, 2009, p. 78) Filosofia é filosofar. E filosofar é 


\title{
Aoristo)))))
}

\section{International Journal of Phenomenology, Hermeneutics and Metaphysics}

trabalhar no "movimento de penetração, sondagem e ausculta atenta do sentido do ser, que incessantemente emerge do abismo desvelante da vida". (HARADA, 2009, p. 79) Filosofar é destruir, isto é, des-montar todo o dado, todo o dito e o feito, para remontar a esse abismo e, assim, liberar a passagem para a gênese criativa do mundo. Filosofia é uma "redução" (reductio), isto é, uma re-condução de todo o nosso ser ao abismo desvelante das possibilidades do ser, ao abismo da vida. É um "Itinerarium mentis in nihilum".

Filosofia não tem conteúdo. Melhor: seu único conteúdo é sua forma mesma de investigação, de busca do sentido do Ser. É crescer e con-crescer com a gênese da realidade dando-se e retraindo-se nas realizações do real: "é a dinâmica de precisão e sensibilidade no ler entre linhas, isto é, do intelecto". (HARADA, 2009, p. 91) É permanecer, sempre de novo, na disposição do não-saber, na espera do inesperado. É, sempre de novo, co-nascer com a nascividade da gênese da realidade. É, a cada vez, abrir-se à imensidão abissal do Ser. É o exercício da pobreza do espírito no cuidado do intelecto:

Na Filosofia, propriamente não se tem conteúdo. Tudo que ali aparece como conteúdos, p. ex., explicações, argumentos, descrições da realidade, termos, conceitos, são materiais do exercício da colocação das questões, que no fundo, são um único empenho e intrépido movimento de, em sondando e auscultando, buscar o sentido do ser, que emerge nas Lebenswelte, da imensidão abissal do ser. E o sentido do ser não é nenhum conteúdo determinado, mas sim um desvelar-se do Abismo da serenidade do Nada, que afeiçoa cada vez mais a nossa busca, a sabermos cada vez menos, a fim de nos dispormos cada vez mais, a melhor ouvir, a melhor auscultar e a melhor receber as novas possibilidades de ser, emergentes dessa plenitude abissal do Nada. Essa busca, quanto mais busca, tanto mais se torna pura disponibilidade da espera auscultante do inesperado, na total pobreza do saber, na plenitude do vazio de uma recepção atenta, na vulnerabilidade da finitude alegre e grata. (HARADA, 2009, p. 91-92)

No permeio das realizações do real que estão se dando a toda a parte, no permeio das vicissitudes humanas e de suas destinações, ou seja, das produções, das criações, das ações, das lutas, dos amores, das oferendas, das ciências, das mundividências, sim, das "filosofias", pensador é o homem que procura praticar esta radical disposição de, na pobreza do não-saber, dispor-se ao sentido do Ser. $\mathrm{Na}$ produção da técnica e na criação da arte, no êxtase da música e da dança, nas oferendas da religião, nos mitos e nos mistérios, nos ritos e cultos, no cuidado com os mortos, na edificação das cidades, na luta pelo poder da dominação, na liberdade do jogo, na transfiguração de Eros, na autonomia do pensar e em seu questionamento radical, na pesquisa da ciência está sempre atuando a compreensão do ser do ente no todo. O homem está sempre sendo instado a responsabilizar-se pelo sentido do Ser,

\author{
Marcos Aurélio Fernandes \\ Toledo, v. 4, n*1 (2021) p. 217-249
}




\section{Aoristo)))))}

International Journal of Phenomenology, Hermeneutics and Metaphysics

isto é, a resguardar a unidade simples de céu e terra, mortais e divinos. Dito de outro modo: o homem, enquanto homem, irrompe no real na medida em que a realidade, enquanto realidade, irrompe no homem. Irrompe: se torna aberta e manifesta, enquanto tal. "Nessa irrupção e por ela os seres florescem naquilo que são e como são. É a irrupção florescente que, à sua maneira, ajuda os seres a virem a si mesmos". Essa irrupção é experiência (páthos: disposição, afinação), compreensão e linguagem (discurso: fala, escuta, silêncio). Filosofia é filosofar. E filosofar é deixar acontecer o evento dessa irrupção. Pensar é auscultar o apelo silencioso do sentido do Ser dandose por toda a parte e a todo o momento. É auscultar o clamor do abismo do sentido do Ser. Filosofia é a sempre a mesma, mas nunca igual, realização desta ausculta. O que ela tem de perene é, justamente, esta disponibilidade finita de ausculta. Aprender e ensinar a pôr-se nesta ausculta é a profissão do filósofo. É o seu serviço à humanidade. Esta profissão requer uma espécie de "voto de pobreza" que é exercido no trabalho do intelecto. Ser filósofo é ser operário, artesão, nesse trabalho. Filosofia é, para recorrer a Kierkegaard e sua exposição a respeito dos estágios da existência, uma busca ética. Nas palavras de Harada:

(J) Todos os grandes Pensadores na Filosofia entenderam a essência da Filosofia como Questão do sentido do ser.

(K) A Questão do sentido do ser, a disponibilidade atenta da ausculta, na plenitude da espera do inesperado, que constitui a essência da Filosofia, não deve ser confundida com vivência "mística" de "passividade" pietista. Antes, é o movimento intenso de trabalho intelectual, i. é, o empenho máximo de, no permeio da materialidade desta ou daquela vicissitude da existência humana (esta obra, este autor, esta arte, esta questão, etc.), exercitar-se na disponibilidade, que realmente penetre no Abismo de profundidade do sentido do ser. Nesse equívoco de identificar a esperado inesperado com a passividade pietista cai o vitalismo, o espontaneísmo, o espiritualismo, eivados de esteticismo. Essa espera do inesperado, na plena atenção no permeio do trabalho árduo e intenso, é antes um labor operário, corpo a corpo com o sentido da Vida. Exige engajamento de toda a nossa liberdade, de todo o nosso ser humano.

(L) Na linguagem de Kierkegaard a disponibilidade da espera do inesperado é o estágio ético, levado a sua máxima consumação.

Entretanto, o que há com a outra busca, aquela da religiosidade e da religião, melhor dizendo, aquela da fé cristã e de seu desdobramento na teologia? Como nela soa e ressoa o clamor abissal? Tentemos refletir a respeito disso.

\section{A FÉ: SEU ABISMO E SUA POBREZA DE ESPÍRITO}

Aqui e agora nos toca o desafio de deixar vir à fala, fenomenologicamente, a estruturação interna da experiência fática da existência chamada "fé cristã". "Hic Rhodus, hic salta!". Na dificuldade de dar este salto, vamos recorrer a uma "indicação 


\title{
Aoristo)))))
}

International Journal of Phenomenology, Hermeneutics and Metaphysics

\author{
formal" fenomenológica, exposta por Heidegger em sua conferência "Fenomenologia \\ e Teologia". \\ Chamamos de "cristã" à fé. O adjetivo "cristã" concerne, mais que ao \\ cristianismo, fenômeno derivado, à "cristicidade", fenômeno originário.
}

A essência da fé pode ser delimitada formalmente do seguinte modo: a fé é um modo de existência do ser-aí humano que, segundo sua própria testemunha - pertencente essencialmente a esse modo de existência - não é temporalizado a partir do ser-aí e por seu intermédio, por sua própria decisão, mas a partir daquilo que se revela nesse e com esse modo de existência, a partir daquilo que é crido. $\mathrm{O}$ ente que é primariamente revelado para a fé e apenas para ela, o ente que, enquanto revelação, temporaliza pela primeira vez a fé, é para a fé "cristã" o Cristo, o deus crucificado. A relação da fé com a cruz, determinada por Cristo, é uma relação cristã. A crucificação, porém, assim como tudo o que está ligado a ela, aponta para um evento histórico, e, em verdade, esse evento, como tal, é testemunhado na Escritura em sua historicidade específica apenas para a fé. Só se "sabe" deste fato na fé. De acordo com seu caráter específico "de sacrifício", o que assim se revela possui o seu direcionamento comunicativo determinado na direção do homem individual historicamente existente, a cada vez de maneira fática, seja contemporâneo ou não, ou à reunião desses indivíduos enquanto comunidade. Enquanto revelação, essa comunicação não é uma transmissão de conhecimentos sobre acontecimentos reais, passados ou ainda por vir. Ao contrário, ela transforma os indivíduos em "participante" no evento que é a revelação $=$ o que nela é o próprio revelado. Esse tomar-parte, porém, que não se realiza senão no existir, só se dá como fé e pela fé. Todavia, nesse "tomar-parte" e "ter-parte" no acontecimento da crucifixão, todo o ser-aí se coloca diante de Deus como cristão, isto é, como alguém referido à cruz; e essa existência tocada por essa revelação torna-se manifesta para si mesma em seu esquecimento de Deus. E, assim, segundo seu sentido - eu falo sempre apenas de uma construção ideal da idéia o ser colocado diante de Deus representa uma guinada no posicionamento da existência na e pela misericórdia de Deus apreendida pela fé. A fé, portanto, nunca compreende a si mesma senão crendo. $\mathrm{O}$ crente não sabe e jamais sabe algo a respeito de sua existência específica, baseando-se, por exemplo, em uma constatação teórica de vivências internas; ao contrário, ele só pode "crer" nessa possibilidade de existência como uma possibilidade cujo ser-aí que é tocado nada pode a partir de si, na qual o ser-aí se tornou escravo, é trazido para diante de Deus e, com isto, volta a nascer. Por conseguinte, o sentido existencial próprio da fé é: fé = renascimento. E, em verdade, renascimento não no sentido de ser dotado momentaneamente de alguma qualidade, mas renascimento como

\author{
Marcos Aurélio Fernandes \\ Toledo, v. 4, n*1 (2021) p. 217-249
}




\section{Aoristo)))))}

International Journal of Phenomenology, Hermeneutics and Metaphysics

modo do existir histórico do ser-aí faticamente crente no interior da história, renascimento que começa como o evento da revelação; na história, à qual, segundo o sentido da revelação, já foi imposto um determinado fim extremo. O evento da revelação, que se transmite à fé e, por conseguinte, acontece na própria credulidade, só se desvela à fé. Lutero diz: "fé é entregar-se-como-cativo às coisas que não vemos" (Erl. Ausg. WW. 46, 287). Só que a fé não é algo por meio do qual - no qual se revela meramente o acontecimento da salvação como um evento, ou seja, ela não é em certa medida um modo de conhecimento diversamente modificado, mas, enquanto apropriação mesma da revelação, a fé constitui concomitantemente o acontecimento cristão, isto é, o modo de existência que determina o ser-aí fáctico em sua cristicidade como uma destinação específica. A fé é um existir credulamente compreensivo no interior da história que se revelou, isto é, que aconteceu com o crucificado. (HEIDEGGER, 2008, p. 63-64)

Não podemos, nos limites desta reflexão, aprofundar este texto. Não vamos falar dele. Mas pretendemos falar desde ele. Vejamos, pois.

Um primeiro prolegômeno desta reflexão: a distinção entre crença e fé. Usualmente, nós confundimos crença e fé. Em nossa consideração, aqui, porém, convém distinguir ambos os fenômenos. Mas crença é fenômeno que se situa no horizonte do conhecimento, do saber. E fé, por sua vez, é fenômeno que se situa no horizonte do ser, do existir. A crença é forma de assentimento que está entre a opinião e a certeza. A opinião é objetivamente e subjetivamente insuficiente. A crença é objetivamente insuficiente, mas, subjetivamente, é dotada de certa evidência (uma certa convicção subjetiva). A certeza, por sua vez, é uma forma de assentimento que é suficiente tanto objetiva quanto subjetivamente (uma convicção subjetiva fundada objetivamente).

Fé não significa, aqui, uma crença religiosa - uma convicção subjetiva, íntima, que, vista desde o ponto de vista do saber e de sua exigência, aparece como objetivamente incerta, acabando por ser algo como uma adesão irracional, refratária à compreensão, inacessível. Saltemos, pois, da dimensão do conhecimento, do saber, para a dimensão do ser, do existir. Se nossa interrogação se volta para o ser, para o existir humano, eis o que se nos presenta e apresenta, imediatamente: a facticidade. Eu sou... Tu és... Nós somos. Entretanto, de início e na maior parte das vezes, esse fato e sua facticidade se encobre na obviedade do que nos é o mais familiar, corriqueiro, habitual. E o sentido de ser desse "eu sou", "tu és", "nós somos", a existencialidade da existência, a facticidade, se retrai, e nós igualamos esse sentido de ser (existência) com a mera ocorrência, com a factualidade de um mero estar aí, presente ante à mão. Ou então nós representamos esse sentido de ser partindo dessa ocorrência aí e acrescentando a ela algo assim como consciência. Assim, a existencialidade da existência acaba sendo interpretada a partir das vivências da consciência e das suas intensidades. Mas, o que dizer, por exemplo, de alguém em estado "terminal", apenas "vegetando", como costumamos dizer, numa cama de UTI, cujo nível de consciência é bem baixo, quase nulo? É verdade, porém, que para 


\section{Aoristo)))))}

International Journal of Phenomenology, Hermeneutics and Metaphysics

nós, que consideramos uma tal pessoa em uma tal situação, ela não se confunde com um mero objeto, nem como algo como uma pedra, como uma planta, etc. Ali jaz alguém e não algo... um si-mesmo... Esse, o "si-mesmo" não se deixa determinar a partir da consciência, nem do eu... Pelo contrário, é o eu, é a consciência, que se determina a partir do si-mesmo. O "eu sou", o "tu és", o "nós somos", se dá, cada vez, a partir de um já ser si-mesmo... E este já ser si-mesmo se põe no nível mais profundo e elementar da facticidade, que se dissimula em factualidade.

Entretanto, o que estamos querendo dizer com "facticidade" do existir humano? Facticidade: esta presença a priori, anterior a toda tomada de consciência, esta vigência da existência, da abertura de ser para o ser de tudo o que é, na qual nós já nos encontramos lançados, saibamos ou não, gostemos ou não. Ora, o saber da facticidade não resulta de nenhuma explicação. É um saber "em sendo", dado com a e como a experiência mesma de existir. Toda consciência, toda vivência, todo a explicação e sentido produzido e tematizado a partir de e através de explicação já chegam tarde. Experiência é evidência: mas é evidência de um "full contact", isto é, de um contato direto, imediato, corpo a corpo, com a coisa ela mesma, que, aqui, se chama ser, existir. A dimensão a priori, elementar, do ser, do existir, é a dimensão de todas as dimensões, é a abertura de todas as aberturas, isto é, de todas as descobertas, de todos os desvendamentos, etc. Esse saber "em sendo", imediato, da facticidade, é o abrir-se da "clareira do Ser". Esse modo de ser ser, esse sentido de ser, que nós chamamos, aqui, de facticidade, e que tem o caráter de liberdade da verdade, com outras palavras, de franqueamento da abertura da revelação do Ser, é o que chamamos de "clareira do Ser".

\subsection{DA FÉ PRIMORDIAL COMO EXPERIÊNCIA ONTOLÓGICA}

O espiritual, de que tratamos acima, concerne a essa abertura. Em vez de "o espiritual", também podíamos nomear esta dimensão chamando-a de "o místico". A mística é o fato de ser dessa facticidade. Mística é o mistério da experiência de ser, de existir, dando-se na e como facticidade ela mesma. Neste sentido, a vigência da mística é universal, está se dando em todo o lugar e em todo o tempo em todas as vicissitudes do existir humano. Neste sentido, todo o homem, saiba ou não, goste ou não, é místico. A mística constitui a própria condição de seu ser: uma vez que ele está sempre fincado na relação com o mistério da experiência de ser, de viver, de existir. Em vez de "mística" poderíamos chamar também de "fé". Mas "fé", aqui, não tem a ver com determinação de uma tradição religiosa. Não se trata de uma fé confessional. Trata-se de uma fé primordial, que coincide com o sentido do Ser, vigente na unidade mística do real, do Todo, melhor, do abismo desvelante das possibilidades de ser. Trata-se de um Todo vazio - mas este vazio é fecundo, pois, é pleno de possibilidades de ser. Trata-se de um Sentido indeterminado, mas que, como origem e princípio, em seu frescor e nascividade, deixa ser as realizações de todo o real. 


\section{Aoristo)))))}

International Journal of Phenomenology, Hermeneutics and Metaphysics

Fé primordial é, aqui, o fincar pé e ficar de pé na abertura da revelação do mistério do Ser; é o ser abrigado e sustentado na verdade do Ser. A verdade do Ser é o apoio, o abrigo, a morada do homem. É a partir desse apoio que o homem se ergue a si mesmo e se rege no seu vigor de ser próprio. Crer é, neste sentido, a positividade de perdurar, insistir, persistir, perseverar no crescimento e amadurecimento do simesmo desde a e na verdade do Ser. Este crer, portanto, não exclui o buscar, o questionar. Pelo contrário. É pelo buscar e questionar que o homem pode se dispor para um relacionamento livre com a verdade do Ser. Essa é a fé primordial que vige no pensar. Heidegger aponta nesta direção ao dizer:

Os perguntadores deste tipo são os originária e propriamente crentes, ou seja, aqueles que, fundamentalmente, tomam a sério a verdade mesma e não somente o verdadeiro; aqueles que põem a decisão se a essência da verdade vige e se esta vigência nos carrega e nos conduz, a nós, os que sabem, os que creem, os que agem, os que criam, em breve, os históricos. (HEIDEGGER, 1994, p. 369)

A fé primordial, portanto, concede ao homem o abrigo, a morada e o apoio para o buscar e questionar, que é próprio do pensar. Pensar é, aqui, sondar o fundo do ente. É medir-se com a abissalidade do Ser. O Ser é o mais confiável. Se nem sempre o homem confia no ente, por este lhe trazer tantas inseguranças e incertezas, do Ser ele se fia. Este lhe parece um fundamento não problemático, seguro, no cotidiano. E, no entanto, para o pensador, que sonda o fundo ou o fundamento do ente, o Ser se lhe doa como abismo (sem-fundo). É dessa fé primordial que surgem, na esfera do "espiritual" (tal como acenado acima) as diversas experiências criadoras de pensamento (de relacionamento com o mistério do Ser): a mística de viver e morrer, o relacionamento com o Alto (a parusia superior do Sagrado em suas hierofanias, teofanias, epifanias), isto é, com o Sublime do mistério do Ser, mais precisamente, com o Sagrado e com o Santo, com os deuses no acontecer de suas doações, como o extraordinário das cintilações do mistério de Ser, e com o Deus em suas teofanias culminâncias das ontofanias; a arte, a música e a dança, com seus êxtases, o mito com sua linguagem ressonante e a poesia, com sua linguagem cantante; e, enfim, a filosofia, com sua experiência do Lógos. Os tempos arcaicos das teogonias testemunham o viger dessa fé primordial. Essa fé primordial é, em sua abertura universal, católica (katà tòn hólon - segundo o Todo), isto é, ecumênica: sua envergadura abraça e abrange toda a habitação humana (oikouméne) sobre toda a Terra (katà hòlen tèn gén). Todos os modos de o homem se relacionar com o Sublime, com o Sagrado, com o Divino, são partícipes dessa fé primordial. O que usualmente chamamos de "crenças religiosas", em suas tradições nas várias humanidades da terra, são modulações dessa fé primordial, universal, ecumênica. São modos de existir e de se relacionar com o mistério de Ser que perpassa a existência.

$\mathrm{Na}$ historicidade destas experiências do Divino, o Deus recebe muitos nomes. Como dizia um fragmento de Heráclito (fr. 67): "O mistério (ho theòs): dia-noite, inverno-verão, guerra-paz, saciedade-fome, cada vez que entre fumaça recebe um 


\title{
Aoristo)))))
}

International Journal of Phenomenology, Hermeneutics and Metaphysics

nome segundo o gosto de cada um, se apresenta diferente". (ANAXIMANDRO, PARMÊNIDES, HERÁCLITO, 2017, p. 89) "Trata-se de um texto extraordinário", diz Paul Ricoeur, "enquanto são os diversos perfumes, talvez dos sacrifícios, que, mediante os seus aromas, coloram o deus de nomes diferentes" (RICOEUR; BLATTCHEN, 2000, p. 15). A experiência humana do mistério do Ser dando-se na sua mais alta parusia, a do Divino, está situada entre o Inominável e a profusão dos Nomes Divinos. (RICOEUR; BLATTCHEN, 2000, p. 13) Para o Inominável acena aquela evocação concedida a Moisés pelo Deus de Abraão, de Isaac e de Jacó, quando este lhe pergunta pelo seu Nome, e este responde: "Eu sou aquele que sou!". (Ex. 3, 14) Aqui, a redundância do verbo "Ser" acena para o retraimento do Inominável. Nada é dito - se dizer é apresentar algo como uma ocorrência ao alcance da mão. Apenas se acena para o Indizível. Melhor: este Nome diz (mostra) o Indizível (o que se oculta como mistério). Nada é dado a compreender, apenas se acena para o Incompreensível.

Crer é, para o homem, existir em face do mistério de muitos nomes, mas que, em última instância, silencia-se como o Inominável. Crer é ser compreendido pelo mistério Incompreensível. É calar-se, abismar-se, no seu silêncio. O divino se degenera em ídolo, cada vez que o homem perde esta dimensão do silêncio que vige e que reina desde o mais profundo e o mais alto do mistério do Ser. É o que evoca a experiência do "bezerro de ouro" dos hebreus no deserto, cultuado por eles, enquanto Moisés, no alto do Sinai, recebia as instruções do Deus que se anunciou com aquelas palavras: "Eu sou aquele que sou". O ídolo é o divino sem mistério. O ídolo é o divino manipulável, disponível à mão, o divino prestável, útil, isto é, servível para os interesses e projetos e necessidades humanas. É o pseudo-divino, o anti-divino, enfim. Idolatria é o homem não deixar o divino ser o divino que ele é... capturando-o nas malhas do uso e das representações humanas, nas redes da relação sujeito-objeto. É a pretensão de reduzir o divino a objeto de vivência e de manipulação, sim, de poder, de dominação, de controle. Idolatria, é religião sem o vigor da fé primordial, originária. É religião sem o hermético do divino.

\subsection{A FÉ PRIMORDIAL COMO FÉ ABRAÂMICA: SEU ABISMO E SUA POBREZA DE ESPÍRITO}

A fé primordial, originária, deixa aparecer o mistério do divino como outro, totalmente outro. É o mistério por excelência: o hermético, o fechado em si. Não se pode dizer que ele é isso ou aquilo, senão que ele é ele mesmo. Essa tautologia assinala, porém, a sua fuga no retraimento. Revelando-se, ele se desvela como o que se vela, e diz de si que ele é "Aquele que é". Ele não é nenhuma possibilidade nossa. É a impossibilidade de todas as nossas possibilidades. Mas esse impossível desde nós mostra-se como o possível desde ele mesmo. Em virtude dessa absoluteza, Nicolau de Cusa preferiu evocar o divino como o "Não-outro", isto é, o que está inteiramente

\author{
Marcos Aurélio Fernandes \\ Toledo, v. 4, n*1 (2021) p. 217-249
}




\title{
Aoristo)))))
}

International Journal of Phenomenology, Hermeneutics and Metaphysics

solto de toda a relação. Tudo está relacionado com ele, mas ele, não está pendente de nenhuma relação. Rombach, elucidando o sentido desse "non aliud" do Cusano diz:

\begin{abstract}
A determinação esse [ser] não se lhe atribui no ressaltar e distinguir (Abhebung) contra outo ente, também não simplesmente contra o não ser, mas livre de todo ressalto e distinção, este ser significa uma determinação pura em sua essencialidade mesma e em plena positividade e inteira determinidade. Deus é aquilo que não mantém sua determinidade não primeiramente através de limites em face a outro, mas se plenifica totalmente a partir de sua própria essência. Portanto, ele não precisa de um outro, sim, em face a este ente não há nada, que seria "outro", que poderia conter determinações, que não já tivessem alcançado já na essencialidade de Deus sua máxima realidade. Deus é aquilo, que não é limitado por nada e do qual nada de outro poderia se excluir. Por isso ele se dá no nome "não-outro". (ROMBACH, 1966, p. 152)
\end{abstract}

Esse Outro que é melhor dito "não-outro" é-nos mais íntimo do que nós a nós mesmos. Por isso, "Não-outro" não indica uma distância inalcançável sem indicar também, dialeticamente, uma proximidade da qual nós não podemos nunca nos distanciar, por ser "intimius intimeor meo", nas palavras de Agostinho (Confissões livro III - 6, 11): "Tu autem eras interior intimo meo et superior summo meo" (Tu, porém, eras mais dentro de mim do que o meu mais íntimo e mais elevado em relação a mim do que o que de meu há de mais elevado). (AUGUSTINUS, 1960, p. 114)

Para a fé primordial que se desdobra na fé abraâmica, porém, este Outro que é melhor dito não-outro e que nos é mais íntimo do que o nosso mais íntimo, é um Tu. Ele interpela e é interpelado como um Tu. Todo o universo está incluído na relação $\mathrm{Eu}-\mathrm{Tu}$ (talvez seria melhor chamar essa relação de Tu a Tu). A fé abraâmica é, por assim dize, uma relação absoluta com o Tu absoluto. $\mathrm{O}$ desapego, a renúncia, nada tem de privação e negação degradantes, dizem, antes um modo de recondução e de inclusão de tudo na relação absoluta com este Tu absoluto, na experiência do encontro com Ele:

Na relação com Deus, a exclusividade absoluta e a inclusividade absoluta se identificam. Aquele que entra na relação absoluta não se preocupa com nada mais isolado, nem com coisas ou entes, nem com a terra ou com o céu, pois tudo está incluído na relação. Entrar na relação pura não significa prescindir de tudo, mas sim ver tudo no $\mathrm{Tu}$; não é renunciar ao mundo mas sim proporcionar-lhe fundamentação. Afastar o olhar do mundo não auxilia a ida para Deus; olhar fixamente nele também não faz aproximar de Deus, porém, aquele que contempla o mundo em Deus, está na presença d'Ele. "Aqui o mundo, lá Deus" tal é uma linguagem do Isso; assim como "Deus no mundo" é outra linguagem do Isso. Porém, nada abandonar, ao contrário, incluir tudo, o mundo na sua totalidade, no 


\section{Aoristo)))))}

International Journal of Phenomenology, Hermeneutics and Metaphysics

$\mathrm{Tu}$, atribuir ao mundo o seu direito e sua verdade, não compreender nada fora de Deus mas apreender tudo nele, isso é a relação perfeita. Não se encontra Deus permanecendo no mundo, e tampouco encontra-se Deus ausentando-se dele: Aquele que, com todo o seu ser, vai de encontro ao seu $\mathrm{Tu}$ e lhe oferece todo ser do mundo, encontra-o, Ele que não se pode procurar. Sem dúvida Deus é o "totalmente Outro". Ele é porém o totalmente mesmo, o totalmente presente.

Sem dúvida, ele é o "mysterium tremendum" cuja aparição nos subjuga, mas Ele é também o mistério da evidência que me é mais próximo do que o meu próprio Eu.

Na medida em que tu sondas a vida das coisas e a natureza da relatividade, chegas até o insolúvel; se negas a vida das coisas e da relatividade, deparas com o nada; se santificas a vida, encontras o Deus vivo. (BUBER, 2009, p. 89-90)

Enquanto o Outro, o totalmente outro, que é Não-outro, que é totalmente ele mesmo, desde ele mesmo, presença que tudo permeia e abraça, e que habita no mais fundo da alma, no âmago do ser humano, qual centelha (Mestre Eckhart), isto é, vigendo como uma faísca, uma cintilação, que, encontrando no humano a disponibilidade e disposição, tudo ilumina e incendeia, sempre de novo, em repentinos adventos, o Deus da fé é evocado como o inacessível, mas é experimentado como inacessível propriamente não por ser inalcançável, por ser impossível de se atingir, a partir de nossas possibilidades, antes, é experimentado como inacessível propriamente na medida em que vem ao encontro do homem, interpela-o, apresenta-se-lhe como um Tu que o toma também por um tu, entrando em diálogo com ele. Por isso, a fé, como possibilidade de ser, de existir, é a própria revelação desse Deus que fala ao homem. A fé é a fé de Deus ("genitivo subjetivo"!). É a impossibilidade tornando-se possibilidade. O Deus da fé se revela na fé de Deus, isto é, a fé, enquanto a priori, é Deus crendo no homem. É a absoluta positividade de Deus no encontro com o homem. Sem a fé de Deus, revelação do seu mistério enquanto mistério, a fé do homem, isto é, o seu nascer, crescer e consumar na liberdade da verdade de Deus, não se dá. Embora esta revelação apareça como um advento e uma irrupção do totalmente outro na experiência humana, este evento não é "exterior" ao homem, é, antes, uma iluminação interior, que cresce desde o âmago do homem, e que não lhe sobrevém e advém como algo que lhe é estranho, antes, sobrevém e advém como aquilo que lhe é o mais íntimo e o mais familiar, por si. A questão é que o homem, alienado de si mesmo, vivendo no esquecimento de Deus, muitas vezes já se perdeu de si e já se perdeu de Deus, o que a experiência da fé chama de "pecado" (o que nada tem a ver com uma categoria moral). O reino de Deus, a vigência da fé, só pode sobrevir ao homem, por já brotar de dentro dele.

A fé religiosa, no sentido abraâmico, se dá e acontece como uma experiência transcendental. Deus não é nenhum objeto. Na relação sujeito-objeto o homem não 


\section{Aoristo)))))}

International Journal of Phenomenology, Hermeneutics and Metaphysics

pode encontrar e experimentar Deus. Toda forma de consciência que se move nessa relação, se encontrar algo como Deus, estará lidando com um Isso. $\mathrm{O}$ Tu divino se retrai da relação sujeito-objeto (como também o tu humano e todo tu). O encontro com Deus acontece na ruptura da relação sujeito-objeto, eu-isso. Somente quando cai a tela da objetividade é que o Tu irrompe como o totalmente outro, o não-outro, que nos é o mais íntimo. O Deus do encontro, o Tu divino, não é um algo entre outros algos. Ele não é uma parte do mundo, não é fato, não é objeto do mundo. Para o crente, isto é, o que existe na possibilidade do crer, ele é o Único. E este Único é Tudo (Deus meus et omnia - Deus meu e tudo!, sentença de Francisco de Assis que se tornou mote dos franciscanos). O crente, como o pensador e o poeta, não é um homem de fatos e de parcialidades e objetividades. Fé é uma experiência transcendental, ontológica, como o pensar e o poetar. Por isso, a respeito do divino a ciência, que é uma experiência que se move na relação derivada sujeito-objeto, nada pode falar, nem afirmar nem negar. (cf. ROMBACH, 2004, p. 148) Experiências transcendentais, ontológicas, são herméticas. A linguagem de crentes, poetas e pensadores, neste sentido, apenas deixa ser a ressonância da experiência com a experiência. Tem o caráter de testemunho, melhor, de testamento. É martírio (no sentido originário grego de martyrion).

A fé vigora sempre de novo como irrupção da experiência do divino, que abre passagem, e inaugura sua própria dimensão. Fenomenologicamente, trata-se de uma "dimensão", isto é, da dimensão do divino, da "dimensão-Deus". (ROMBACH, 2004, p. 159) O mundo dos deuses e do Deus dos deuses é o mundo em que os crentes se movem, enquanto crentes. A linguagem do mito se desdobra neste mundo como um infinito narrar. A linguagem da fé abraâmica, por sua vez, se desdobra como narrativa de uma história de salvação.

O Deus uno cristão é, na realidade, uma vida divina desdobrada ou interpretada no infinito relato do evento da salvação, ofertada em inesgotáveis configurações. - Onde Deus é só Deus, ali ele não é. Só onde vive e age, dirige e eleva, que, enquanto princípio de sentido, ele leva à plenitude uma ordenação superabundante, para o interior da qual conduzem incontáveis experiências. Experiências singulares, ou melhor, individuais e indubitáveis. (ROMBACH, 2004, p. 159)

O crer, como o pensar e o poetar, não se move no horizonte de um pensamento objetivo. Aqui trata-se do horizonte do mistério do Ser, onde toda a experiência de verdade é experiência do advento do inesperado. Tanto o crer, como o pensar, como o poetar, vivem da e na espera do inesperado. O crer retoma a experiência da verdade do Ser, porém, em outra modalidade, em outro tom ou entoação, e numa dinâmica de sentido diversa. $O$ crente não vive a vida da fé a partir dele mesmo e em vista dele mesmo. O existente, aqui, é "servo" (não é a partir de si e a partir de si). Melhor, é filho. A existência da fé e na fé tem o sentido de novo nascimento. O crente vive na liberdade dos filhos de Deus. Existir como crente é estar disposto e exposto 


\title{
Aoristo)))))
}

\section{International Journal of Phenomenology, Hermeneutics and Metaphysics}

ao mistério da fé. O homem precisa aprender a empenhar todo o seu existir na experiência da fé, desde si mesmo, no mais radical desapego. A fé não se dá e acontece sem o desprendimento sempre de novo exercido e exercitado pelo crente, em "temor e tremor". A fé é o dom de uma conquista. Mas é, ao mesmo tempo, a conquista de um dom. "O homem não escolhe, mas é escolhido pelo mistério de sua fé". (LEÃO, 2008, p. 222-223)

A vigência dessa fé primordial está acontecendo por toda a parte e a todo o momento no exercício de ser, de existir, do homem. Em sendo, em exercendo a sua existência, o penhor da realização humana, de sua conquista da cordialidade de viver, da serenidade jovial e da jovialidade serena, já lhe foi dado como essa fé primordial. Só a partir da confiabilidade no mistério de Ser, é que o homem pode se empenhar por vir a ser o que ele é. É a partir dessa confiabilidade que ele trabalha, produz, cria, luta, ama, filosofa, conhece, sofre, morre. É essa fé primordial que concede ao homem a possibilidade da espera do inesperado - espera que, de repente, se transforma em esperança.

No mistério de Ser brilha o sublime. Fé, neste sentido primordial, é o recolhimento da existência humana no sublime do mistério de Ser. O sublime da emergência e da subtração do mistério de Ser já está operando em tudo o que o homem faz ou deixa de fazer. Tudo o que o homem faz ou deixa de fazer já é sempre uma correspondência a esse sublime. Esse sublime é anterior a toda sublimação, como a mística é anterior a toda a mistificação. É dádiva e penhor. Todo o mérito, todo empenho humano e sua competência, já o pressupõe. E, no entanto, só a duras penas, numa longa caminhada de libertação, é que o homem conquista um relacionamento livre com esta dádiva. A conquista deste relacionamento livre não se dá sem esforço e sem exercício (ascese). Mas também não se em virtude do esforço e do exercício (ascese).

De certa feita, um jovem entrou para um mosteiro a fim de alcançar a libertação pelos rigores do claustro e pela disciplina da meditação. $\mathrm{O}$ mestre saiu para o pátio, apanhou um caco de telha e se pôs a esfregálo numa pedra de esmeril. Passou dias inteiros concentrado no esforço de esmerilar a argila. $\mathrm{O}$ recém-chegado se aproximou e indagou o que o monge pretendia com todo aquele trabalho. $\mathrm{O}$ monge respondeu que, raspando com todo o cuidado, ia transformar o caco de telha num espelho. $\mathrm{O}$ noviço retrucou: então, pode desistir. Caco de telha, por mais que se raspe, não vira espelho. O monge comentou apenas: pensei que você não sabia. Como não, disse o jovem. Todo mundo sabe que espelho é metal e não barro. O monge concluiu: libertação não é esforço de meditação. (LEÃO, 1990, p. 21)

Como seria ler a vocação de Abrão - tornado Abraão, o "pai dos crentes" - à luz dessa fé primordial? Abrão, filho de Térah, de Ur dos Caldeus (de clã arameu?), sob o comando de seu pai, sai de sua terra e vai habitar em Harran, na curva do Eufrates.

\author{
Marcos Aurélio Fernandes \\ Toledo, v. 4, nं1 (2021) p. 217-249
}




\section{Aoristo)))))}

International Journal of Phenomenology, Hermeneutics and Metaphysics

Ali ele ouve do Deus desconhecido o chamado para partir para uma terra desconhecida. "Parte da tua terra, da tua família e da casa de teus pais para a terra que eu te mostrarei". (Gn 12,1) Nessa saída, nesse êxodo, Abrão se torna um crente, melhor, um vidente, isto é, um homem que vê no visível o invisível e no invisível o visível e que, daí, haure a segurança de seus passos na direção do desconhecido. (cf. $\mathrm{Hb} 11,27)$ Fé é ter-sido-cativado pelo invisível do mistério. Ter-sido-cativado e tersido-libertado é o mesmo, aqui, como no amor. É que se trata de Encontro com um Tu absoluto. A fé é sustentação em uma palavra que se lança para o futuro e em favor do futuro - a palavra de uma promessa divina -; ela é um dar prova daquilo que não se vê. (cf. Hb 11, 1)

Deus é o "éschaton" - o extremo vindouro, a destinação última e definitiva - do homem. O caráter escatológico, porém, da fé é não negativo, já que o definitivo não nega o provisório, o último não nega o penúltimo; mas, o porvindouro, o adveniente, vige, reina, já agora, no presente, só que sua vigência é a vigência de uma ausência, de um ainda-não. É algo assim como uma gravidez. Na dinâmica sempre libertadora de um constante a-caminho, toda a dor é dor de parto. É por isso que a Epístola aos Hebreus, no Novo Testamento, lê a história de Abraão sob o signo do escatológico. Do mesmo modo aparecem as histórias dos mais antigos patriarcas da humanidade cujas sagas são narradas no Gênesis -, dos patriarcas de Israel, de Moisés, dos líderes carismáticos dos primórdios (os “juízes"), de Davi e dos profetas. (Hb 11)

A fé requer do homem uma constante vigilância escatológica. Nessa dinâmica escatológica, o homem sempre de novo é posto à prova. Ele pode se ganhar ou se perder. Mas ele só se ganha se ele se perde. Caso ele busque se auto assegurar naquilo que é possibilidade sua, ele se perde. Caso ele se perca disso e se ancore no que o transcende, ele se ganha. Em virtude desta dinâmica escatológica, a fé precisa sempre de novo se expor à possibilidade da não-fé. Uma fé que não é assumida nesta exposição, torna-se mera comodidade. A possibilidade da não-fé não é representada pela dúvida e sim pela infidelidade. No horizonte da fé, a dúvida não é um mero ato de consciência que torna problemática uma opinião, uma convicção. A dúvida é a divisão da alma, é a duplicidade, que denuncia a perda da simplicidade do coração, que, por sua vez, remonta à infidelidade do amor e à incapacidade da espera e da esperança, que se ancoram no radical outro (é indício de impaciência, de desesperança ou de desespero).

A fé é um chamado de ser e para ser, caminhando do conhecido para o desconhecido do mistério. Por isso, ela é carregada de "temor e tremor" (como bem viu Kierkegaard, ou melhor, como bem evidenciou, na forma de uma lírica dialética, Johannes de Silentio). (KIERKEGAARD, 1995, p. 181-297) É uma experiência análoga à confiança, pela qual um ser humano se confia e se entrega a outro humano, num relacionamento de tu a tu, a partir da dádiva de um encontro (tomamos esta palavra com o peso que lhe foi dado por Martin Buber). A fé é uma paixão - algo como um enamoramento (cf. toda a linguagem da mística esponsal na história das religiões abraâmicas). Mas, como toda a paixão, e todo o enamoramento, não é cega, é visionária. Não vê de menos. Vê demais. O saber da fé, a sua vidência, é a iluminação 


\section{Aoristo)))))}

International Journal of Phenomenology, Hermeneutics and Metaphysics

imediata, que é dada com a própria fé e na própria fé. Por isso, o saber da fé é hermético. Ele se abre desde dentro da própria fé. Aqui todo o saber é sabor de experiência feita. Aqui todo o conhecimento é co-nascimento, melhor, re-nascimento.

Crer é algo assim como o centro de um encontro no in-stante do enamoramento [...]. Em nosso sentido, enamoramento designa aquela realidade que se "constitui" no encontro das pessoas como sua origem, como seu centro: formulamo-lo com as palavras, já muito desgastadas: relação-eu-tu.

Experimentamos por assim dizer um crescimento de ser, e esse novo ser "é" o saber a partir de dentro. "Sabemos" porque "somos". É nesse sentido que a Sagrada Escritura fala de um "conhecer" no amor esponsal. "Crer" é portanto a evidência originária do ser, é a profundidade originária, a partir donde outros "saberes" haurem suas "evidências". Nesse sentido, a base originária de toda ciência é "crer".

(...) A admiração de São Francisco diante do ser, é, portanto, um conhecimento da criança (Kind), mas não mais da criança ingênua que não questiona, mas a admiração é o ser-si-mesmo originário como "crer": é a figura da evidência originária como Ser-aí.

Nesse sentido, essa admiração se encontra além de todo questionar e duvidar: a admiração é a vida originária da criança divina. (HARADA, 2003, p. 138-139)

A fé é algo assim como o ocular, a ótica, do encontro. O encontro é abalador. Ele retira do familiar e envia para o desconhecido. Mas é a afeição, dádiva do encontro, que carrega e sustenta o homem no embalo de seu salto, que lhe permite não temer o desconhecido. É que, para o homem que busca segurança no já conhecido, o desconhecido não é somente o ainda não conhecido, é o que se lhe mostra como perturbador. Ser um crente é saltar no abismo do desconhecido, é caminhar esperando contra toda esperança... Mas este salto não é cego... Não é um salto no escuro, como se diz muitas vezes. Pelo contrário, é o salto de uma iluminação. $\mathrm{O}$ crente caminha com a evidência da afeição, do amor, que surge como dádiva do encontro com o Tu absoluto (o Radical-Outro, o Não-Outro). Na fala do Deus de Abraão, que se tornou o Deus dos hebreus e o Deus dos cristãos, vibra um envio de ser abissal, um comando inaugural, originário e originante de história. É uma fala que desperta a esperança de um porvir, em que a Terra se torna terra acolhedora e fértil, lugar de vida plena e de criação fecunda. É uma fala que nos torna, sempre de novo, pre-cursores, preparadores para os porvindouros, para a descendência. A espera do inesperado se torna em esperança e essa se torna, no presente, princípio fecundo, fonte de criatividade. Essa esperança leva a assumir, sempre de novo, no presente, o passado mais arcaico. Faz desvendar nesse passado o vigor criativo da criação - e toda criação, enquanto criação, é "de nihilo" (desde o Nada). 


\section{Aoristo)))))}

International Journal of Phenomenology, Hermeneutics and Metaphysics

Deus não cria apenas a partir do nada, no sentido de criar sem recorrer a qualquer matéria. Deus cria a partir do nada de si (do retraimento de seu mistério). E, no entanto, Deus, o radical-outro, que é não-outro (segundo o sentido do Cusano, acima exposto), não recusa, antes acolhe e promove, uma integração com o ser do ente, com o que para nós aparece como real e realidade, a saber, o mundo. À luz da fé primordial, o chamado da fé é um apelo de ser e para ser. Por isso, é no mistério do Ser, que abre o mistério da existência, que vige e vigora o vigor da fé. O envio da fé é um encaminhamento de ser e para ser. Na experiência da fé se dá a sonância e a ressonância do mistério do Ser de um modo bem peculiar. Ser não é nada objetivo, nem subjetivo. Não é predicado de um objeto. Não é atividade de um sujeito. Ser, aqui, não é o modo de ser (essência), nem a efetividade ou atualidade (existência) do ente. Ser não é nenhuma algo que se constata nem é nada que se deixa constatar naquilo que consta, que se presenta e se apresenta aí, como ocorrência, como dado ante a mão. Ser, assim entendido, não se contrapõe ao devir, nem ao aparecer (aparência), nem ao pensar, nem ao dever. Tudo isso, o devir, o aparecer, o pensar, o dever, já estão sob a égide do Ser e em tudo isso está se dando (e se subtraindo) a vigência do mistério do Ser. Ser, assim entendido, não se contrapõe a não-mais-ser e a não-ainda-ser. (cf. HEIDEGGER, 2001, p. 161) Tanto o não-mais-ser como o aindanão-ser pertencem ao vigor de ser. Ser vige tanto na realidade, quanto na necessidade, quanto na possibilidade (modalidades). Vige tanto na diferença, quanto na identidade, tanto na multiplicidade quanto na unidade. Ser vige tanto na presença como na ausência. Aliás, escuta melhor o apelo abissal do Ser e a ele melhor responde e corresponde quem consegue perceber a ausência como vigor ainda mais entranhado de ser ser.

Se for assim, então outro seria o sentido da "falta de Deus e do divino" na história dos homens. Essa falta tem o caráter de ausência. O relacionamento entre o homem e o Deus e o divino se dá entre a vigência da presença e a vigência da ausência, entre a proximidade e a distância, entre o abrir-se e o clarear-se e o cerrarse e adensar-se da clareira do Ser. A vigência do Ser se dá tanto como a patência da presença, quanto como a latência da ausência. Heidegger observou que a experiência do divino, tanto para os hebreus quanto para os gregos, se desdobrou sob a vigência da ausência (latência):

O erro (sic) ${ }^{2}$ de Deus e do Divino é ausência. Mas ausência não é um nada. Ausência é precisamente a vigência apropriadora da plenitude velada do ter-sido e assim do que, reunido no modo do ter-sido, vige e é. Ausência é a vigência do divino para os gregos, para os judeus profetas, para a pregação de Jesus. Esse não-mais é, em si, um aindanão do advento velado de seu vigor inesgotável. Um vez que ser nunca é apenas o real dado, vigília do ser não pode, de forma alguma, equiparar-se à função de um vigia, que protege tesouros conservados num imóvel contra possíveis assaltantes. A vigília do ser

\footnotetext{
2 "Fehl". Preferimos traduzir por "falta".
} 


\title{
Aoristo)))))
}

International Journal of Phenomenology, Hermeneutics and Metaphysics

não está siderada pelo simplesmente dado. No simplesmente dado, quando tomado em si mesmo, nunca se encontra um anúncio do ser. A vigília é uma vigilância, um zelo pelo destino de ser, já sempre resguardado e adiantado, já tendo sido e sendo porvir. É vigilância a partir de um pensamento cuidadoso que sempre se renova, que presta atenção ao aceno em que ser se acena. (HEIDEGGER, 2001, p. 162)

Na vigilância escatológica da fé caminharam os profetas de Israel (do norte e do sul). Os profetas são os sentinelas do porvir. São os guardiães que, na noite do mundo, vivem a vigília do ser, o zelo pelo destino espiritual da Terra. São os prenunciadores do novo éon, os precursores da parusia do Deus vindouro.

\subsection{A FÉ DE JESUS CRISTO NA FÉ DE SÃO FRANCISCO: SEU ABISMO E SUA POBREZA DE ESPÍRITO.}

João Batista apareceu no deserto da Judeia testemunhando toda a tensão dessa vigilância escatológica da fé. Nesta mesma atmosfera de espera e de vigilância escatológica foi que apareceu Jesus de Nazaré, o Cristo, com sua pregação do Reino de Deus. O testemunho de Jesus de Nazaré inaugura um novo testamento da fé. $\mathrm{Na}$ fé que chamamos de "cristã", Jesus, o Cristo, é o anunciador (hermeneús) do Reino de Deus, a quem ele chama de Pai $(A b b a)$. Esse "Reino", porém, ele inaugura e consuma em si mesmo, na sua própria vida e morte, como o Crucificado. Assim, ele se mostrou como a testemunha por excelência do Reino. Ele se evidenciou para os seus discípulos como o "autor (archegòn) e consumador (teleiotèn) da fé (tes písteos)". (Hb $12,2)$

A consumação da fé se deu na sua morte de cruz: no máximo da dor e do amor, ele grita: "Meu Deus, meu Deus, por que me abandonaste?" (Mc 15, 34). Eis que ele se aniquila participando, como inocente, da negatividade destruidora do mal, que traz consigo a mais dura desolação. Ele desce até ao abismo infernal. E, na plena afeição obediente de um Filho de Deus, diz: "Tudo está consumado. E inclinando a cabeça, entregou o espírito". (Jo 19, 30) A sua dor de amor foi o recolhimento (Lógos) mais profundo nas profundezas abissais da mortalidade e da errância humana. Em seu grito recolheu-se todo o clamor que o humano ergue "de profundis..." a Deus, a quem Jesus chamou de Pai... Mas sua entrega foi a consumação da fé, feita oferenda de um amor absolutamente gratuito - sem por quê. Essa fé consumada é que faz raiar a aurora do domingo da Páscoa, da ressurreição, acendendo o fogo da jovialidade do espírito na terra dos homens, definitivamente.

A revelação da fé de Cristo, numa tradução hermenêutica do Prólogo de São João, vertida por Emmanuel Carneiro Leão, soa assim:

No princípio era a Linguagem e a Linguagem estava no Mistério e a Linguagem era Mistério. Toda palavra veio a ser língua por ela e sem

\author{
Marcos Aurélio Fernandes \\ Toledo, v. 4, n*1 (2021) p. 217-249
}




\section{Aoristo)))))}

International Journal of Phenomenology, Hermeneutics and Metaphysics

ela nenhuma língua se fez língua. O Sim estava nela e o Sim era a língua dos homens. O Sim resplandece no não e nenhum não nega sem o Sim. A jovialidade enviada pelo Mistério fala do Sim de sorte que nela os homens creem no Sim. A jovialidade não é o Sim mas vem na revelação do Sim, como a língua em que os homens se entendem. A Linguagem estava no mundo, nela o mundo chegou a si mesmo mas nela o mundo não se reconheceu. Adveio na língua dos homens e os homens não a entenderam mas aos que a entenderam, deu o vigor do Mistério, deixando falarem as palavras do Sim. E assim a Linguagem se fez língua e atendou entre as palavras, cheia da jovialidade, da verdade e da revelação do Mistério. (LEÃO, 2008, p. 207)

Na fé de Jesus Cristo - fé consumada na oferenda da cruz - há como que uma niilidade toda própria, que São Francisco de Assis chamava de "Domina Paupertas", "Madonna Povertà" (Senhora Pobreza). Trata-se da pobreza de espírito substanciada na humildade e na caridade do Cristo que "aniquilou-se a si mesmo, assumindo a condição de servo por solidarismo com os homens. E, apresentando-se como simples homem, humilhou-se, feito obediente até a morte, até a morte da cruz". (Fl 2, 7s) "Kénosis", "exinanitio" - esvaziamento, despojamento: assim soa a niilidade vigente no mistério de Cristo. O crístico do mistério de Cristo é caracterizado pela identidade dinâmica de Deus e homem ("encarnação"). A arte gótica medieval captou o vigor e a ternura desse mistério nos seus crucificados, nas figuras de Maria com a criança divina-humana, e nas suas "pietà". O absoluto, por e para ser absoluto, não exclui o criatural em sua finitude, em sua vulnerabilidade, em sua fragilidade. O espírito, por e para ser pura positividade, cordialidade, jovialidade de viver, não exclui a matéria, não exclui a carne, assume sobre si e para si o mal, o mistério da iniquidade, a culpa humana até seus grotões mais profundos. Eis, então, que o "Senhor" se torna o "Servo" (servo do servo!), o "Glorioso" mostra sua glória, justamente, como o "Crucificado", homem das dores, sem beleza, menos que um homem, um verme, alguém consumido pelo seu amor ardente pelos homens; como a "criança" divinahumana, em sua fraqueza, inocência e graciosidade; como o pão eucarístico. "Ó humildade sublime! Ó sublimidade humilde!", exclama São Francisco na admiração da fé na sua "Carta a toda a Ordem". (SÃO FRANCISCO DE ASSIS, 2020, p. 101) A divina sublimidade, por assim dizer, se encolheu para dentro do humano, demasiado humano. A transcendência divina se ofereceu na inaparência da transcendência da transcendência, a nobreza divina assumir a vileza da condição humana, terra a terra. "Nudus Christus in nudo ligno" (Cristo nu no madeiro nu). Deus se abisma no homem e, ao mesmo tempo, o homem se eleva em Deus. Nisso, São Francisco de Assis via a figura cheia de ternura e vigor da "Senhora Pobreza" (Madonna Povertà, Domina Paupertas). Na "Introdução dos tradutores"(entre os quais contava também o frei Hermógenes Harada) ao opúsculo "Sacrum Commercium", nas "Fontes Franciscanas", lemos:

A senhora Pobreza é o modo de ser, inaugurado, vivido e consumado na Terra, trazido do Céu por Jesus Cristo, do abismo do Mistério do

No entremeio de abismos: entre pensamento e fé 
International Journal of Phenomenology, Hermeneutics and Metaphysics

Amor, chamado Santíssima Trindade. É a revelação do mais íntimo recolhimento do Deus de Jesus Cristo, Deus que nos amou primeiro; é ternura e vigor do Deus que se tornou um de nós, viveu humilde e pobre, morreu crucificado e deu-se a nós até sua última gota de sangue, para nos testemunhar quão intensa, profunda e misericordiosa é a paixão do seu amor.

Em assumindo, como manifestação da sua benevolência, a nossa carne mortal, em sustentando todas as vicissitudes da nossa finitude, suas necessidades, suas negatividades, Jesus Cristo, Crucificado, pobre e humilde, ensinou-nos que a essência, a mais íntima da sua divindade, não se revela naquelas categorias "meta-físicas", enumeradas pela filosofia como, por exemplo, onipotência, onisciência, infinitude absoluta, mas, antes, na imensidão, profundidade abissal e disponibilidade livre do Amor-Misericórdia. Amor misericordioso, revelado na Boa-Nova do Evangelho como generosidade silenciosa do pudor do Mistério, do Encontro de Amor, que em se dando sem medidas, humilde e discretamente, com a finura da delicadeza e da sensibilidade do "Amor Feminino", não se faz senhor, mas servo, ao entregar-se totalmente, dando toda a sua riqueza de graça, faz-se pobre a modo de mendigo, mendigando a nossa livre benevolência para com Ele.

Esse Amor-Misericórdia, revelado em pessoa no modo de ser de Jesus Cristo, pobre e humilde, é o pano de fundo da paisagem rochosa da espiritualidade franciscana. Ela é benigna, silenciosa e imensa, como o Céu e a Terra; ela abraça cuidadosa e benignamente a caminhada da passagem íngreme e estreita, cheia de perigos e aventuras, do Encontro de Amor da nossa finitude mortal com o Amor que nos amou primeiro, Amor Infinito que se faz finito, recolhido, ocultando-se na gruta da senhora Pobreza, como o Natal de um Novo Céu e Nova Terra. (ANÕNIMO, 2020, p. 875-876)

O "nous" (pensamento) de Cristo - melhor, sua "sophía" (sabedoria) - se esconde no mistério deste esvaziamento, deste rebaixamento, da humildade e da caridade da cruz - mistério que para São Francisco emergiu na imagem da "Senhora Pobreza". Essa "sophía" é aquilo a que Paulo se referia quando dizia: "os judeus pedem sinais (semeia aitousin), e os gregos procuram a sabedoria (sophían zetousin), enquanto nós pregamos Cristo crucificado, escândalo para os judeus, loucura para os gregos, mas poder e sabedoria de Deus para os chamados, quer judeus, quer gregos". (1 Cor. 1, 22-24) Paulo alude à vigência da niilidade no evento da principiação e consumação da fé no evento da cruz de Jesus Cristo com as palavras: "o que não é nada (tà mè ónta), Deus escolheu para destruir o que é (tà ónta)”. (1 Cor. 1, 28) O vigor ontológico da mensagem do evento Cristo Crucificado se esconde na dinâmica meontológica da sua encarnação, e de sua consumação na sua paixão e morte de cruz. Nela se doa uma "sophían en mysterío" (sabedoria misteriosa), "transcendente", "hermética", "abissal”. Trata-se de uma sabedoria pneumática: "a nós, porém, Deus

$$
\begin{array}{r}
\text { Marcos Aurélio Fernandes } \\
\text { Toledo, v. 4, n'1 (2021) p. } 217-249
\end{array}
$$




\section{Aoristo)))))}

\section{International Journal of Phenomenology, Hermeneutics and Metaphysics}

revelou pelo Espírito. Pois o Espírito esquadrinha tudo, até as profundezas de Deus". (1 Cor. 2, 7.10)

São Francisco quis que o Evangelho fosse sua forma de vida. Com outras palavras: que fosse o vigor estruturante de sua vida, a vida de sua vida. Quis que o seguimento, o discipulado do, a conformidade e a co-nascividade ("imitação") com o mistério do Cristo Crucificado, o Deus menor (o máximo que se fez mínimo), fosse o princípio estruturante de seu ser, de seu viver. Quis ser pequeno, humilde, pobre, no amor ardente por tudo e por todos, como Jesus Cristo, o Deus menor. Entendeu que a identidade do cristão não residia em nenhum poder, mas no não-poder e na ternura da caridade humilde, que não exclui nada nem ninguém - caridade católica, isto é, universal, uma identidade aberta a todas as diferenças e diferenciações. Harada via na paixão de São Francisco pela "Senhora Pobreza", um niilismo sui generis:

O nihilismo de Francisco, porém, nada tem a ver com o nihilismo em sentido usual, justo por ser ainda mais radical: sim, poderíamos dizer que o nihilismo de Francisco é ainda mais realista, mais objetivo, mais transparente e desprovido de ilusões: ele não lamenta, não vê as coisas mais escuras, nem sequer chega à ideia de ser pessimista, pois isso tudo é ainda um sintoma de que o nada não é levado a sério, de que o nada é considerado ainda um valor, mesmo que seja um valor negativo: Se o nada é nada, então naturalmente as coisas estão "ruins" para nós.

Mas o característico em Francisco é que nele esse tomar ciência do nada não é um conhecimento no sentido usual. É precisamente e até um tomar ciência no sentido de: ele é nada. Nesse sentido, Francisco é um dos maiores metafísicos do mundo. Nele não há: primeiro eu, depois o objeto e depois conhecimento. Ele é sempre e a cada vez o meio, e só depois "conhece" o objeto. Mas nesse ser-meio, Francisco é sempre radicalmente nada. Ele não tem substância, nenhum peso, nenhum fundamento, nenhuma tradição, nenhum mérito, constantemente, a cada in-stante é vazia e abertamente nada. Esse ser-nada é o mais radical tomar ciência e acolher do ser-criatura: um tomar ciência e acolhimento que nada têm a ver com o nosso querer ou conhecer: as coisas são assim, algo diverso me é simplesmente impossível: nada a não ser o próprio ser-criatura.

Menor, menos, mais baixo que esse nada nada há. Ser mais nada do que esse nada é simplesmente impossível. Isso significa imediatamente: Minoritas!. (HARADA, 2014, p. 132)

A niilidade de Francisco de Assis é uma niilidade agradecida, serena, jucunda, jovial. É uma niilidade que, qual abertura da liberdade plena concedida pela pobreza de espírito, deixa-ser tudo no seu vigor de ser mais próprio (Ereignis!). Nela, ôntico e ontológico coincidem. Aqui, ser vige, cada vez, como gênese do que está sendo, desde o nada, no nada. Ser é a nascividade se dando desde o nada. O ser-nada do homem acontece, então, como o "aí" (Da) do Ser (Seyn). A existência humana aparece como a "aberta do Ser". Ser vige, no nada, desde o nada, "como dinâmica nasciva 


\title{
Aoristo)))))
}

International Journal of Phenomenology, Hermeneutics and Metaphysics

cordial do surgir, concrescer e consumar". (HARADA, 2004, p. 90) Ser vige como a positividade cordial, nasciva da Vida. Ser vige como vida que vem à fala ora como o inexorável paredão maciço, ao mesmo tempo estranho, oculto, misterioso fundo, ora como terna, jovial e generosa simplicidade na imensidão, ora como insondável profundidade abissal da facticidade. (HARADA, 2004, p. 91) A niilidade de São Francisco é uma niilidade agradecida com a graça do Ser, da Vida. O Evangelho, como "forma de vida", como "regra" (o que rege, põe de pé, orienta, direciona), é o sentido de Ser que surge desta experiência abissal.

\section{2 À GUISA DE CONCLUSÃO: O ABISMO INVOCA O ABISMO - NA NIILIDADE DE HOJE UMA NOVA VIRADA PARA O DIVINO NAS EXPERIÊNCIAS ONTOLÓGICAS DO PENSAR E DO CRER?}

A presença do Deus e do divino não contradiz a ausência, antes, é algo assim como a vigência de uma ausência, uma latência, o velamento originário do mistério. A parusia de Deus brilha na luz noturna do Nada do mistério. Para nós, que vivemos sob o signo da "des-divinação", (HEIDEGGER, 2002, p. 98) isso é decisivo.

Bernard Welte colheu no niilismo de nosso tempo uma virada para uma nova experiência do Divino. Vislumbrou o "olho divino" dando-se sob a forma desconcertante do "Nada", em que se nos abre a dimensão do divino. Teria sido a partir daí que o poeta T. S. Eliot, autor de "Four Quartets", teria dito: "I said to my soul, be still, and let the dark come upon you. Wich shall be the darkeness of God" ? (apud WELTE, 1990, p. 47) É também desde aí que o poeta Paul Celan. (apud WELTE, 1990, p. 142) teria escrito o poema: "Mandorla" (auréola)? Esse poema soa assim:

In der Mandel - was steht in der Mandel?

Das Nichts.

Es steht das Nichts in der Mandel.

Da steht es und steht.

Im Nichts - wer steht da? Der König.

Da steht der König, der König.

Da steht und steht.

Judenlocke, wirst nicht grau.

Und dein Aug - wohin steht dein Auge?

Dein Aug steht der Mandel entgegen.

Deim Aug, dem Nichts stehts entgegen.

Es steht zum König.

So steht es und Steht.

Menschenlocke, wirst nicht grau.

\author{
Marcos Aurélio Fernandes \\ Toledo, v. 4, n・1 (2021) p. 217-249
}




\title{
Aoristo)))))
}

\section{International Journal of Phenomenology, Hermeneutics and Metaphysics}

Leere Mandel, königsblau.

Tentemos uma tradução:

\author{
Na auréola - o que está na auréola? \\ O nada. \\ O nada está na auréola. \\ Está aí ele e está.
}

No nada - quem está aí? O Rei.

Aí está o Rei, o Rei.

Aí está ele e está.

Cachos dos cabelos do judeu, não se encanece.

E teu olho - para onde se volta teu olho?

O teu olho está em face à auréola.

O teu olho, está em face ao nada.

Ele está voltado para o Rei.

Assim está ele e está.

Cachos dos cabelos do homem, não se encanece.

Vazia auréola, azul real.

Para onde, afinal, está voltado o nosso olho? Para a auréola, o brilho do sagrado? Conseguimos, afinal, perceber o brilho do sagrado, resplandecendo na noite do mundo? Está nosso olho voltado para o nada? E, no nada, percebemos o estar do Rei? Estamos face a face com Ele como a um $\mathrm{Tu}$ ? Nos tornamos pobres o bastante para fincar pé nessa relação originária? Pobres o bastante para sermos ricos com o seu dom, para com sua auto-doação?

Talvez esta reflexão seja algo assim como uma senda perdida. Acabamos no intransitado. Mas, deixemos, por fim, uma palavra que pode servir-nos de aceno para um futuro abrir-caminho no denso cerrado da existência, quer na modalidade do pensamento que se faz filosofia, quer na modalidade da fé que se faz entrega de si ao "Amor não amado". (S. Francisco de Assis)

Esse aceno concerne ao "pensamento do Ser" (HEIDEGGER, 1997, p. 205-213). Ele foi anotado por frei Hermógenes Harada, ao presentear o autor que aqui escreve com o seu livro - "Em comentando I Fioretti". (HARADA, 2003) Para nós, este aceno pode aludir à proximidade entre o pensar (enquanto outro) e a fé - como que deixando-nos pressentir algo daquela sim-patia e sin-tonia que há entre um e outro, na sua oposição mesma, relacionamento que, no entendimento de Harada, deixa-se nomear na expressão do salmo 41/42: "abyssus abyssum invocat" (um abismo invoca outro abismo):

Nimm die letzte Glut der Segnung erst vom dunklen Herd des Seyns, dass sie zünde die Entgegnung: Gottschaft - Menschentum in Eins. Wirf die Not der kühnen Lichtung zwischen Welt und Erde als 
Gesang aller Dinge zur Errichtung frohen Danks an Fug und Rang. Birg ins Wort die stille Kund eines Sprunges über Gross und Klein, und verlier's die leeren Funde jähen Scheins im Gang zum Seyn.

Toma o último ardor da bênção só da escura lareira do Ser, que ele acenda a contraposição: deidade - humanidade no Um. Lança a precisão da audaz aberta entre mundo e terra como loa de todas as coisas para a ereção de alegre gratidão no apropriado e na dignidade. Alberga na palavra o silencioso anúncio de um salto por cima de grande e pequeno, e perde os achados vazios do súbito aparecer e brilhar na caminhada para o Ser. (tradução nossa. HEIDEGGER, 1997, p. 4)

\title{
REFERÊNCIAS
}

ANAXIMANDRO, PARMÊNIDES, HERÁCLITO. Os pensadores originários. Petrópolis: Vozes, 2017.

ANÔNIMO. Sacrum Commercium. In: Fassini, Dorvalino e Oliveira, Aloísio de. Fontes Franciscanas (p. 871-906). Santo André-SP: O Mensageiro de Santo Antônio, 2020.

AUGUSTINUS. Confessiones / Bekenntnisse. München: Kösel, 1960.

BUBER, M. Eu e Tu. São Paulo: Centauro, 2009.

HARADA, H. Da pobreza. In: Revista de Cultura Vozes. Petrópolis: Vozes, 1977, p.31-42.

. Em comentando I Fioretti: reflexões franciscanas intempestivas. Bragança Paulista / Curitiba:

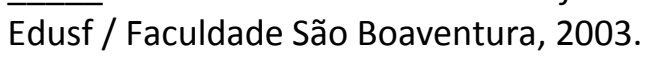

. "Heinrich Rombach, memória e gratidão". Em: Scintilla - Revista de Filosofia e Mística

Medieval, 2004. n. 2, 67-96.

. De estudo, anotações obsoletas: a busca da identidade humana e franciscana. Petrópolis /

Bragança Paulista / Curitiba: Vozes / Edusf/ IFAN / Faculdade de Filosofia São Boaventura, 2009.

107-150.

. A ideia do franciscanismo. In: Scintilla - Revista de Filosofia e Mística Medieval, 2004, n. 2,

HEIDEGGER, M. “Uma palavra de agradecimento". In: Revista de Cultura Vozes, 1977, p. 49-51.

. Metaphysische Anfangsgründe der Logik im Ausgang von Leibniz (GA 26). Frankfurt a.M:

Vittorio Klostermann, 1978. 1994.

. Beiträge zur Philosophie (Vom Ereignis) (GA 65). Frankfurt am Main: Vittorio Klostermann,

. Feldweg-Gespräche (GA 77). Frankfurt am Main: Vittorio Klostermann, 1995.

Besinnung (GA 66). Frankfurt am Main: Vittorio Klostermann, 1997.

Conferências e escritos filosóficos. São Paulo: Nova Cultural, 1999.

“Posfácio (A coisa)". In: M. HEIDEGGER, Ensaios e Conferências. Petrópolis: Vozes, 2001,

p.161-164.

. Seminários de Zollikon. São Paulo / Petrópolis: EDUC / Vozes, 2001

. Caminhos de Floresta. Lisboa: Calouste Gulbenkian, 2002.

. Marcas do Caminho. Petrópolis: Vozes, 2008.

. Meditação. Petrópolis: Vozes, 2010.

. Zum Ereignis-Denken (GA 73.1). Frankfurt a.M.: Vittorio Klostermann, 2013.

KIERKEGAARD, Sören. "Timore e Tremore". In: S. KIERKEGAARD, Opere (pp. 181-297). Casale

Monferrato: Piemme, 1995.

\author{
Marcos Aurélio Fernandes \\ Toledo, v. 4, n'1 (2021) p. 217-249
}




\section{Aoristo)))))}

International Journal of Phenomenology, Hermeneutics and Metaphysics

LEÃO, Emmanuel Carneiro (1990). "Introdução." Em: S. Agostinho. A cidade de Deus (Contra os pagãos) Parte I (pp. 17-21). Petrópolis: Vozes.

. Aprendendo a Pensar l: o pensamento na modernidade e na religião. Teresópolis: Daimon, 2008.

MERTON, T. A via de Chuang Tzu. Petrópolis: Vozes, 2002.

RICOEUR, P. \&.L'unico e il singolare. Sotto il Monte: Servitium Editrice, 2000.

ROMBACH, H. Substanz, System, Struktur. Die Ontologie des Funktionalismus und der philosophische Hintergrund der modernen Wissenschaft. Band II. Freiburg / München: Karl Alber, 1966.

. Leben des Geistes: Ein Buch der Bilder zur Fundamentalgeschichte der Menschheit. Freiburg: Herder, 1977.

. Strukturontologie: eine phänomenologie der Freiheit. Freibug / München: Karl Alber, 1988.

. "A fé em Deus e o pensar científico". Em: Scintilla - Revista de Filosofia e Mística Medieval, 2004, n.2, p. 145-163.

SÃO FRANCISCO DE ASSIS (2020). “Escritos (Cartas)". Em D. F. Fassini, Fontes Franciscanas (pp. 25161). Santo André-SP: O mensageiro de Santo Antônio.

SILESIUS, A. Il peregrino cherubico. Milano: Paoline, 1989.

WELTE, B. La luce del nulla: sulla possibilità di una nuova esperienza religiosa. Brescia: Queriniana, 1990.

Submetido: 10 de janeíro de 2021

Aceito: 08 de fevereíro de 2021

No entremeio de abismos: entre pensamento e fé 